\title{
Prospects for reconstructing paleoenvironmental conditions from organic compounds in polar snow and ice
}

Chiara Giorio $^{1{ }^{* a}}$, Natalie Kehrwald ${ }^{2 *}$, Carlo Barbante ${ }^{3,4}$, Markus Kalberer $^{1}$, Amy C.F. King ${ }^{1,5}$, Elizabeth R. Thomas $^{5}$, Eric W. Wolff ${ }^{6}$, Piero Zennaro ${ }^{4}$

${ }^{1}$ Department of Chemistry, University of Cambridge, Lensfield Road, Cambridge CB2 1EW, United Kingdom

${ }^{2}$ Geosciences and Environmental Change Science Center, U.S. Geological Survey, Denver Federal Center, MS 980, Denver, CO 80225, USA

${ }^{3}$ Institute for the Dynamics of Environmental Processes, CNR, Via Torino 155, 30172 Mestre (VE), Italy

${ }^{4}$ Department of Environmental Sciences, Informatics, and Statistics, Ca' Foscari University of Venice, Via Torino 155, 30172 Mestre (VE), Italy

${ }^{5}$ British Antarctic Survey, High Cross, Madingley Road, Cambridge, CB3 0ET, United Kingdom

${ }^{6}$ Department of Earth Sciences, University of Cambridge, Downing Street, Cambridge CB2 3EQ, United Kingdom

${ }^{a}$ Now at: Dipartimento di Scienze Chimiche, Università degli Studi di Padova, via Marzolo 1, 35131, Padova, Italy

*Correspondence to: chiara.giorio@unipd.it; nkehrwald@usgs.gov

\section{Notes}

Authors are in alphabetic order except for the corresponding authors who are at the first and second place.

\section{Abstract}

Polar ice cores provide information about past climate and environmental changes over periods ranging from a few years up to 800,000 years. The majority of chemical studies have focused on determining inorganic components, such as major ions and trace elements as well as on their isotopic fingerprint. In this paper, we review the different classes of organic compounds that might yield environmental information, discussing existing research and what is needed to improve knowledge. We also discuss the problems of sampling, analysis and interpretation of organic molecules in ice. This review highlights the great potential for organic compounds to be used as proxies for anthropogenic activities, past fire events from different types of biomass, terrestrial biogenic emissions and marine biological activity, along with the possibility of inferring past temperature fluctuations and even large-scale climate variability. In parallel, comprehensive research needs to be done to assess the atmospheric stability of these compounds, their ability to be transported long distances in the atmosphere, and their stability in the archive in order to better interpret their fluxes in ice cores. In addition, specific decontamination procedures, analytical methods with low detection limits (ng/L or lower), fast analysis time and low sample requests need to be developed in order to ensure a good time resolution in the archive. 


\section{Keywords}

41 organic compounds, molecular markers, ice core, polar, environmental proxies 


\section{Introduction}

43 Over the last half century, ice cores have provided a wealth of information about past climate and environmental changes (Jouzel, 2013) over periods ranging from a few years up to 800,000 years. For example, ice core results demonstrate the pattern of glacial-interglacial cycles (Epica community members, 2004), the existence of abrupt climate changes (Johnsen et al., 1992), and quantify how greenhouse gas concentrations increased above their pre-industrial values over the last two centuries (MacFarling Meure et al., 2006). The findings are based on three types of information recorded in ice cores: the isotopic content of the water molecules themselves, the gaseous content of air bubbles trapped in the ice (e.g. $\mathrm{CH}_{4}, \mathrm{CO}_{2}$ ), and the impurities that are trapped in or on snowflakes. This last component consists both of aerosol particles and of gaseous compounds that are absorbed onto snow surfaces. Multiple studies quantify many different analytes, and discuss, for example, atmospheric transport of dust, past variations of sea ice, and changes in concentrations of pollutants. The overwhelming majority of studies concentrate on the inorganic impurity - major cations and anions, trace elements, and simple components such as hydrogen peroxide. However, a very large proportion, often half or more, of atmospheric aerosols are organic (Jimenez et al., 2009), and such material is certainly present in polar ice.

Very few studies investigate the organic component in polar ice, either as a whole (Legrand et al., 2013), or for individual compounds. There are probably a number of reasons for this shortage: analytical issues, a lack of expertise in the ice core community, and difficulties in interpreting changing concentrations of reactive chemicals which may have relatively short lifetimes and limited stability in the atmosphere. Many of the studies that do exist concern: (a) very small molecules such as formaldehyde and low molecular weight organic acids (e.g. Legrand and De Angelis, 1995), (b) methanesulfonic acid (MSA) as a specific marker for marine biological activity and/or therefore sea ice extent (e.g. Curran et al., 2003), and (c) organic markers for biomass burning (Gambaro et al., 2008; Rubino et al., 2016). Studies in ice and snow of persistent organic pollutants (POPs) (Fuoco et al., 2012; Hermanson et al., 2005; Ruggirello et al., 2010) and of other molecules such as long chain fatty acids that are potential terrestrial biomarkers as they are produced by land-dwelling plants (Hopmans et al., 2004 and references therein; Kawamura et al., 1996; Pokhrel, 2015; Pokhrel et al., 2015) have been carried out but are not well developed in ice from the polar ice sheets.

Recent advances in analytical capability and in atmospheric chemistry modelling make it the right time to survey the field of organic geochemistry in ice cores and to discuss potential fields of study. Here, we consider only material in the solid ice phase. Air bubbles in ice do contain trace organic gases (such as methane), but these gases pose a different set of issues and are not discussed here. We also do not consider the use of the ${ }^{14} \mathrm{C}$ content of water-insoluble organic compounds to date glacier ice, which was recently reviewed by Uglietti et al. (2016). In this paper, we first review the problems of sampling, quantifying and interpreting the environmental relevance of organic molecules in ice. We then undertake a broad discussion of the different classes of organic compounds that might yield environmental information. Finally, we consider each class in more detail, discussing what has already been done, and what is needed to advance the study of each class.

\section{Challenges with sampling and analysis of organic molecules}

\subsection{General issues during sampling, storage and analysis of organics in ice and snow}

The issues that determine our ability to accurately estimate the concentrations of organic molecules in ice and snow differ with each class of compounds but some general considerations are worth 
discussing. Challenges result from three main issues: (1) individual compounds are expected to be present at low concentrations (typically $\mathrm{ng} / \mathrm{L}$ or lower), posing problems for analytical detection and interferences caused by contamination; (2) the range of physical-chemical properties of organic compounds, especially their polarity, requires a variety of extraction and analytical techniques to quantify the range of organic compounds with optimal sensitivity; (3) some of the compounds may not be stable against chemical reactivity, biodegradation, and volatile loss back to the atmosphere. Concentrations of inorganic compounds also occur at very low levels, and ice core scientists are no strangers to the need to adopt contamination-free protocols (e.g. Boutron and Batifol, 1985). Nonetheless, organic compounds require different protocols, not least because the procedures adopted to avoid contamination for inorganics (e.g. involving clean rooms constructed from clean plastic materials, and the use of plastic sample containers) may be unsuitable for organics.

Field sampling of solid ice cores is challenged by the ubiquitous presence of a host of organic contaminants from both the sampling process and the environment. The most obvious of these impurities is the drilling fluid which keeps the borehole open during deeper ice core drilling projects, and which typically consists of a poorly characterised and variable hydrocarbon mixture but some compounds present in drilling fluid might also be of interest for paleo-environmental markers. The main examples used in recent years are dearomatised kerosenes (D30, D40, D60, with or without added densifier) (Talalay and Gundestrup, 2002), butyl acetate, and the aliphatic ester Estisol series, with or without Coasol (Sheldon et al., 2014). Any such fluid freely coats the outside of all deep cores and remains on the surface throughout transport and storage. However, the advantage of solid ice is that it is impermeable if no cracks penetrate from the outside to the inner core. Therefore, it is possible to shave the outer layer of ice that was coated in fluid, or that has been in contact with plastic bags or organic materials, to obtain clean inner material. A faster way to obtain uncontaminated ice samples for analysis of organic impurity contents is to melt the ice in a way so only the clean inner part is used for the analysis. In this case only the inner section which was never in contact with ambient air and drilling fluid is used and is pumped into a warm lab where it is aliquoted, whereas the possibly contaminated water from the outer part is rejected.

Firn (permeable material that has not yet consolidated into ice, mostly found in the upper 60-100 m of a core depending on the site) and near-surface snow are often more challenging to sample in the field than the deeper, solid ice. Although drilling fluid is not present in the borehole when firn cores are drilled, the cores are vulnerable to contamination from a wide range of other sources: lubricants that may have been used on drill components, spilled liquid and organic vapours in the air (e.g. from fuel used in generators and vehicles and in the laboratories), plastics (bags and bottles) used to contain the ice, and contamination from gloves and other materials used by drillers and core processors. Because of the permeable nature of firn, these materials can penetrate deep into the core (including the entire $\sim 5 \mathrm{~cm}$ radius) through liquid ingress and vapour diffusion. The same issues arise with sampling of surface snow, though collecting large blocks from which more material can be discarded may mitigate the problem. Some molecules may be partly volatile (a process that has been suggested to cause loss from surface snow in situ (Gregor, 1991)) and so sample preservation should include preventing exposure to temperature gradients (i.e. warmer temperatures during transport and storage compared to sampling conditions).

It is difficult to determine what precautions are necessary when sampling snow and firn for individual organic compounds, without first testing to discover whether those individual target molecules, or related interferences, are present in possibly contaminating media such as plastic bags or the atmosphere. However, general studies of organic material in firn and snow argue for the necessity of storing snow samples in airtight and recently pre-cleaned glass bottles (Legrand et al., 
2013) or stainless-steel containers (Domine et al., 2007; Giannarelli et al., 2017; Gustafsson et al., 2005) and avoiding plastics, except perhaps for a low permeability grade of Teflon such as PFAs (i.e. perfluoroalkoxy alkanes). Wrapping firn cores in aluminium foil instead of, or as well as, plastic is also a precautionary measure, which also limits the possibilities for photochemical degradation of some molecules. Maintaining samples in the solid phase rather than as melted samples is preferable for long term storage. However, melted samples can be spiked with $\mathrm{HgCl}_{2}$ to prevent microbial degradation (Kawamura et al., 2012). For some organic molecules, such as MSA it has been shown that diffusional loss through solid ice can be prevented if samples are refrozen as discrete samples (Abram et al., 2008).

In the laboratory, similar precautions are necessary in order to avoid additional contamination from ambient air and possible loss of the analytes. Traditional clean laboratories used by ice core analysts are designed to be low in metal contaminants, but as a result often include numerous plastics, and have particle filters that do nothing to exclude organic vapours. Although it will not always be practical, metal surfaces, ceramic knives, glass and perhaps PFA containers are desirable for trace organic work.

For solid ice, removing the contaminated outer layers of a sample is necessary not only to minimise possible interferences related to coelution in chromatography, matrix effects and competitive ionisation (e.g. if mass spectrometry is used) with analytes of interest likely to be at much lower concentrations than that of the contaminants. Shaving $1 \mathrm{~cm}$ from the outside of cores using a ceramic knife is a commonly used technique (Seki et al., 2015). In following such a procedure, it is critical to avoid transferring contamination from the outside of the core towards the inside on the surface of the knife. Researchers should always scrape in the same direction and should remove ice in a sequence of layers, using a succession of clean knives as used for trace elements analyses (Candelone et al., 1994). Alternative methods involving rinsing the ice with ultrapure water to remove contaminated outer layers are also a common practice (e.g Zennaro et al., 2015). It is not clear whether removal of $1 \mathrm{~cm}$ of ice is sufficient for cracked ice or firn and will depend on the extent and length of the cracks. Due to this uncertainty, sampling radially across an ice core to determine how far external contaminants have penetrated (Boutron and Batifol, 1985) is a necessity.

In recent years, the most popular method for sub-sampling ice cores for inorganic analysis is to melt them on a hot plate, directing only the inner portion of melt to analytical systems in continuous flow analysis (CFA). A similar system for organics might be achievable, but will require many tests to see whether the hotplate and tubing materials are suitable or whether the melter temperatures alter the organic content either due to evaporation, thermal degradation or chemical reaction.

Once a clean subsample has been obtained, the issues of contamination control are similar to those encountered in any organic geochemistry laboratory that analyses samples with low concentrations (Section 2.2). In this respect, one way to minimise contamination is to carry out extraction in situ as soon as possible after sampling and storage of organic extracts either in liquid-phase (Fuoco et al., 2012; Kang et al., 2012; Giannarelli et al., 2017; Vecchiato et al., 2015) or solid-phase extraction materials (Dickhut et al., 2005; Lacorte et al., 2009). A final comment is that the issues discussed above apply to organics as a whole. There may be specific molecules of interest that are not found in significant quantities in drilling fluids, coatings on plastic and in the laboratory environment. However, determining molecules that are not affected by plastic or drilling fluid contamination can only be ascertained by quality control testing for each molecule and in each laboratory. Analytical procedures that are highly selective for a particular molecule of interest (excluding background contamination from interferents) will be advantageous from this viewpoint. 
Here we discuss methods for sample preparation and analysis of organics in polar ice and snow. The discussion focuses on specific markers and does not describe analytical methods for nonspecific compounds that are routinely measured such as greenhouse gases in air bubbles. A more detailed list of methods for each discussed compound/compound class and method performance are available in Section 3 and in Table 1. In cases where many studies exist (e.g. MSA) we only cite a few studies describing the analytical method and its performances. This compilation includes prospective compounds that have not yet been measured in polar ice and snow but have been measured in mountain glaciers.

\subsubsection{Glassware, solvent and reagent decontamination}

A common practice for trace organic analysis is to use high purity solvents (or distilled solvents) and prebaked or prewashed inorganic reagents (Sankelo et al., 2013; Xie et al., 2000). For specific compounds, like fatty acids, solvents may be a large source of contamination that can be reduced by redistillation (Bosle et al., 2014). Common procedures for decontamination of plastic and glassware for inorganic analysis include soaking in ultrapure water, sonication for a typical time of 10-15 mins and additional rinsing (generally three times) with ultrapure water (Jauhiainen et al., 1999). This procedure has proven to be effective for removing inorganic contamination but other procedures are preferable for organics. Müller-Tautges et al. (2014) cleaned all glass containers by baking them at $450^{\circ} \mathrm{C}$ for $8 \mathrm{~h}$. Similarly, Gowda et al. (2016) prebaked all glassware at $450^{\circ} \mathrm{C}$ overnight, followed by rinsing with ultrapure water, methanol and dichloromethane. Rinsing with $n$-hexane (after water and dichloromethane) is also recommended (Piazza et al., 2013) when measuring hydrophobic compounds.

\subsubsection{Sample preparation and analysis}

Organic compounds are present in polar ice and snow samples at trace levels that may challenge many state-of-the-art analytical methods and techniques. For this reason, the vast majority of studies so far have included a pre-concentration step (e.g. Garmash et al., 2013; Grieman et al., 2015; Legrand et al., 1997; McConnell et al., 2007; Pokhrel et al., 2015) with the exception of levoglucosan and vanillic acid which are most commonly analysed without pre-concentration (e.g. Gambaro et al., 2008; Zennaro et al., 2015). The most widely used pre-concentration method is solid phase extraction (SPE) which is applied to non-polar anthropogenic compounds, like polycyclic aromatic hydrocarbons (PAHs), pesticides, polychlorinated biphenyls (PCBs) and perand polyfluoroalkyl substances (PFASs). For non-volatile compounds, another common preconcentration method is solvent evaporation, often using a rotary evaporator (Fu et al., 2016; Kawamura, 1993; Pokhrel et al., 2015; Pokhrel et al., 2016). For some compounds stir bar sorptive extraction has shown potential (Müller-Tautges et al., 2014), however SPE via cartridge and disc materials are currently more versatile due to the availability of a wider range of sorbents, which allows more targeted method optimisations. For volatile compounds, such as volatile halogenated hydrocarbons, purge-and-trap injections, followed by GC-MS analysis, has been used as a preconcentration method for the analysis of Antarctic snow (Zoccolillo et al., 2005).

For PAHs, SPE leads to recoveries of $>80 \%$ in Antarctic snow, with a starting sample volume of $10 \mathrm{~L}$ and limits of detection (LODs) of $0.1 \mathrm{ng} / \mathrm{L}$ using GC-MS analysis (Na et al., 2011). For the same compounds, Gabrieli et al. (2010b) used online SPE on a CFA system and obtained a recovery of $71-93 \%$ and LODs ranging between 0.007 and $0.466 \mathrm{ng} / \mathrm{L}$ using HPLC with fluorescence detection using an initial sample of 250-500 g of melted ice. Kukučka et al. (2010) achieved both 
lower sample volume and lower LODs using solid phase micro-extraction (SPME) followed by thermal desorption and GC-MS analysis. This method gave good recoveries for small PAHs but it did not give satisfactory recoveries for PAHs with 4-6 rings (Table 1). Liquid-liquid extraction (LLE) for PAHs followed by GC-MS has also been used, reaching similar LODs to those of Gabrieli et al. (2010b) but starting with a much larger sample volume of $7 \mathrm{~L}$ (Fuoco et al., 2012). SPE has also been used for a range of different pesticides (e.g. aldrin, DDT), PCBs and PFASs reaching recoveries of $>80 \%$ and LODs in the order of a few $\mathrm{pg} / \mathrm{L}$ (Table 1).

For MSA analysis, a pre-concentration method similar to SPE using a Trace Anion Concentrator (TAC) with an anion exchange sorbent installed on-line in the ion chromatograph has achieved LODs of $20 \mathrm{ng} / \mathrm{L}$ with a $5 \mathrm{~mL}$ starting volume (Curran et al., 2003; Saltzman et al., 1997). Conversely, Jauhiainen et al. (1999) used a large loop injection $(0.8 \mathrm{~mL})$ reaching LODs of $300 \mathrm{ng} / \mathrm{L}$. Saltzman et al. (2006) reached LODs of $100 \mathrm{ng} / \mathrm{L}$ using direct injection with an electrospray ionisation source - triple quadrupole mass spectrometer (ESI-MS/MS) upon sample dilution with methanol (50:50), however direct infusion in an ESI source without prior chromatographic separation has been often criticised for being non-quantitative due to competitive ionisation from non-separated matrix components (Kourtchev et al., 2014).

SPE was used also for pre-concentration of both natural and anthropogenic $n$-alkanes, $n$-alkan-2ones and $n$-alkanoic acids prior to analysis with gas chromatography flame ionisation detection (GC-FID) and GC-MS however recoveries and LODs are not reported (Xie 2000). Fatty acids have also been pre-concentrated by LLE and solvent evaporation using a rotary evaporator (rotavap). Seki et al. (2015) effectively concentrated fatty acids in LLE, followed by saponification with $\mathrm{KOH}$ in methanol and derivatisation with N,O-Bis(trimethylsilyl)fluoroacetamide (BSTFA) before analysis by GC-MS, showing recoveries of $75-82 \%$. Pokhrel et al. (2015) concentrated the samples with a rotavap ( $100 \mathrm{~mL}$ evaporated to dryness) with recoveries $>70 \%$ and LODs of $1 \mathrm{ng} / \mathrm{L}$ with derivatisation with $\mathrm{BF}_{3} /$ butanol followed by GC-MS. A similar method was used for analysing monoterpene and isoprene secondary organic aerosol (SOA) products showing analogous performances (Pokhrel et al., 2016). Pokhrel et al. (2016) used a rotavap and $150 \mathrm{~mL}$ of melted ice after addition of $\mathrm{KOH}$ to convert organic acids into potassium salts making them less volatile, followed by derivatisation with BSFTA and analysis in GC-MS. Similarly, Kawamura et al. (2012) quantified dehydroabietic acid, p-hydroxybenzoic acid, levoglucosan, mannosan and galactosan (all biomass burning markers) by using GC-MS after LLE ( $80-250 \mathrm{~mL}$ of sample) and derivatisation with BSTFA reaching LODs of 3-5 ng/L with recoveries of $67-78 \%$. You et al. (2014) obtained similar performances for levoglucosan, mannosan and galactosan with a smaller ice volume of 5 $\mathrm{mL}$ (Table 1).

Levoglucosan is one of the most widely used biomass burning markers. Gambaro et al. (2008) developed an analytical method for levoglucosan analysis based on direct analysis of melted ice with HPLC-ESI(-)-MS/MS and LOD of $3 \mathrm{ng} / \mathrm{L}$. This analytical method is sensitive for ultratrace determination of levoglucosan in Arctic and Antarctic matrices but it is not able to distinguish levoglucosan from its isomers, galactosan and mannosan. In addition, when this method is applied to continental ice cores, where the matrix generally contains many more impurities, it appears to be less robust (i.e. higher LOD and lower accuracy and repeatability) due to strong matrix effects that reduce the analytical performance (Yao et al., 2013). Yao et al. (2013) developed a new HPLC/ESIMS method that separates levoglucosan from other coeluting water-soluble organic compounds with small sample volumes of a few $\mathrm{mL}$. This method allows the simultaneous quantification of all three isomers, however LODs are more than 1000 times higher than for the method proposed by Gambaro et al. (2008) (10,000 ng/L in Yao et al. (2013) and $3 \mathrm{ng} / \mathrm{L}$ in Gambaro et al. (2008)). 
267 Grieman et al. (2015) developed an analytical method for the analysis of vanillic acid, another biomass burning marker, based on HPLC-ESI-MS/MS which allows fast detection (4 minutes) with a low sample requirement (injection volume of $100 \mu \mathrm{L}$ ) resulting in a LOD of $77 \mathrm{ng} / \mathrm{L}$. Vanillic acid was measured also in ESI(-)-MS/MS upon dilution (50:50) with methanol online in a CFA system (McConnell et al., 2007). Although being able to detect organics online on a CFA system in parallel with the quantification of inorganic compounds would be ideal, analysis by direct infusion is likely to suffer more matrix effects than offline chromatographic methods. Future research is needed to push forward fast chromatographic methods with low detection limits and requiring low sample volume.

\subsection{General issues about interpreting organics in terms of environmental variables}

Interpreting proxies in terms of useful environmental variables is always complex, usually involving issues of production, provenance, transport, lifetime and preservation in the archive.

In the case of polar ice caps, the distance from source to archive is considerable. The Arctic is a "Mediterranean"-style sea, surrounded by boreal forests and by land masses that contain most of the world's population and hence anthropogenic sources. Greenland, in particular, is relatively close to North America, but long-range transport from Asia and Europe can also occur (Kahl et al., 1997). In contrast, Antarctica is entirely surrounded by ocean. Terrestrial and anthropogenic emissions have to be transported in the atmosphere across the Southern Ocean from South America, Africa and Australia. Despite the barrier of distance and circumpolar winds, anthropogenic molecules do reach Antarctica (Kallenborn et al., 2013).

The concentration of a compound archived in an ice core results (sequentially) from (a) its rate of emission from the source (often the variable that really interests us), (b) the location of that source, whose position may change with climate, (c) the proportion of emitted material that arrives over the ice core site (which in turn depends on the transport speed and lifetime), (d) deposition processes, and (e) subsequent loss processes. An additional factor is that many biological emissions are seasonal, so it may be seasonal rather than annual parameters that determine the role of each process mentioned here.

In particular, many aerosol species suffer from the fact that their lifetime before deposition is of a similar magnitude to their transport time from source regions (on other continents, or the surrounding ocean) to Greenland or Antarctica, so that changes in meteorological factors causing changes in transport time or lifetime (often controlled by precipitation) compete with changes due to varying source strength. Simple models have been used to correct for these changes across major climatic changes (such as glacial-interglacial transitions) in the case of inorganics such as terrestrial dust and ammonium (Fischer et al., 2015; Fischer et al., 2007). Some of these issues are avoided when the source is quite close to the ice core site, but this proximity is rarely the case for measurements on polar ice sheets. During relatively short time periods, it may be possible to interpret changes in time while ignoring these considerations. One example of such a situation are persistent organic pollutants (POPs) whose sources increased strongly through the last century. However, natural biogenic emissions are likely to partly change in response to climate variability and therefore separating out climatic influences on the source from other influence factors is tricky.

Most inorganic compounds are chemically stable, and so their lifetime is mainly determined by depositional processes. However, the atmospheric lifetime of many organics is also influenced by photo- and thermo-chemical transformations in the atmosphere that may degrade them, or in some cases form them en route to the polar regions (Kawamura and Bikkina, 2016). Some organic 
molecules may also be re-volatilised or chemically degraded after deposition which may change the proportional loss of the molecule (Kawamura et al., 2001). For example, changing snowfall rates alter the period of time in which chemicals are exposed to sunlight in the snowpack or when changes in snowpack temperature occur (Wolff, 2012). In the best cases, it may be possible to interpret time series of organics in ice with simple analytical methodologies and a straightforward interpretation. However, for more complex molecules an atmospheric modelling approach (using either a transport model, or a chemistry and transport model) may be needed in order to determine what part of the variability can be attributed to changes in source strength (Levine et al, 2011a; Levine et al., 2011b; McConnell et al., 2007; Vecchiato et al., 2015).

The complexities discussed here are applicable to analysis of time series of individual molecules. Comparing multiple organics in the same ice core can help determine the impacts of these complexities. For example, ratios of chemicals with similar source regions and transport, such as ratios of different long chain hydrocarbons, or isotopologues of the same chemical can help resolve the impacts of atmospheric transport on the investigated molecule.

\section{Organic molecules as environmental proxies}

Goldstein and Galbally (2007), estimate that $10^{4}-10^{5}$ separate organic compounds are in the atmosphere. How do we then prioritise which molecules are interesting to investigate in ice cores? The answer must come from a confluence of our ability to measure these compounds in ice and the environmental questions that we would like to answer. Examples of organic markers that have already been detected in ice cores and yielded environmental information are reported in Figure 1. In this section, we outline important environmental aspects and discuss the organic molecules in ice cores that can address these aspects.

\subsection{Terrestrial biogenic markers}

The terrestrial biosphere is the largest emitter of both primary organic aerosols and volatile organic compounds (VOCs) where a fraction of the VOCs is oxidised in the atmosphere forming SOA. VOCs and SOA in ice cores may elucidate how the terrestrial biosphere has changed in recent decades due to anthropogenic land use changes, as well as across rapid climate changes or glacialinterglacial transitions. Measurements of compounds associated with primary emissions (such as leaf waxes) reflect the size of the biosphere while the relative proportions of these compounds may provide information on the composition of the relevant part of the biosphere. Clearly, given the distance of Greenland and especially Antarctica from source regions, interpretation in terms of which source is being sampled and how other factors have influenced the concentrations recorded will be critical for these molecules.

Biogenic VOCs, particularly isoprene and terpenes, are crucial in the atmosphere for many reasons. Emission rates are again expected to scale with the size and composition of the biosphere, modulated by emission factors related to climate. These molecules also play two crucial roles in the atmosphere. They are also a major control on the hydroxyl radical $(\cdot \mathrm{OH})$ concentration in the atmosphere; constraining $\cdot \mathrm{OH}$ concentrations over time would be of interest for many reasons, not least in limiting the causes of methane change over time (Levine et al., 2011b). In addition, biogenic VOCs are on a global level the most important source of SOA, which is increasingly implicated as an important factor in the growth of cloud condensation nuclei (Trostl et al., 2016). It would therefore be very valuable to have proxies for VOC emissions, which will be complicated not only by transport effects but also by lifetime limitations caused by chemical degradation. 
The recent identification of a multitude of biogenic organic markers in snow and ice samples situated both near and far from source regions raises the exciting potential of new environmental proxies that are present in the ice core record. Such compounds have, for example, been found in Alaska (Pokhrel et al., 2015; Sankelo et al., 2013; Yamamoto et al., 2011), the Chinese Himalayas (Xie et al., 2000), Greenland (Grannas et al., 2004; von Schneidemesser et al., 2008), Franz Josef Land, Russia (Grannas et al., 2006), the Tibetan Plateau (Shen et al., 2015) and the Canadian Arctic (Grannas et al., 2004), as well as in oceanic aerosol samples in the Canadian high Arctic (Fu et al., 2013) and over ocean latitudes ranging from the Arctic to Antarctica (Hu et al., 2013). Here we discuss the terrestrial organic compounds so far identified in snow or ice samples, or high latitude atmospheric aerosols, that are most promising as biomarkers in ice.

\subsubsection{Primary emissions}

A number of lipid-based compounds with terrestrial sources have been shown to have long-range transport potential in atmospheric aerosols, and to subsequently be preserved within ice layers. $N$ alkanes, $n$-alkenes, $n$-alkanols, and $n$-alkanoic acids are sourced from terrestrial leaf epicuticular waxes, soil dust, microbial processes or marine phytoplankton (Pokhrel, 2015). Specifically, lipid compounds in epicuticular waxes are plucked from the leaf surface in high winds and entrained in the atmosphere as primary aerosols (Yamamoto et al., 2011), and their concentrations may be expected to demonstrate a record of biogeochemical cycles such as the relative amount of deciduous vegetation and associated carbon storage (Kawamura et al., 1996). Relatively resistant to degradation (Pancost and Boot, 2004), these lipid-based compounds persist in the atmosphere at time scales of days to weeks which allow long-range transportation.

The process of emission, long range transport, deposition and entrainment of lipid-based compounds within snow and ice has been demonstrated in previous work, from both shallow snow pit studies and now extending back to ice layers on the order of several hundred years in age. Identification within shallow snow pits in Japan (Sankelo et al., 2013; Yamamoto et al., 2011) and China (Xie et al., 2000) demonstrate the potential of terrestrial organic compounds to be preserved in snow layers, with the major source of the lipid compounds being large forested regions found more proximally to the deposition sites. Extending to more far-reaching deposition sites, De Angelis et al. (2012) observed terrestrial vegetation and biomass burning emissions dominating the carboxylic acid budget within surface snow layers at Summit, Greenland, concluding that aerosols generated by Northern Hemisphere terrestrial biomass are an important contributor to aerosol deposits in the ice record at this high latitude location. Lipid compounds have further been detected in snow layers dating back to 450 years at Site J in Greenland (Kawamura et al., 1996). Although air masses that pass over Greenland contain a more complex mixture of both marine and terrestrial organic aerosols, Kawamura et al. (1996) were able to identify compounds of specific terrestrial origin using a number of distinguishing molecular characteristics (see below), which have been used and expanded on in subsequent studies (Bendle et al., 2007; Pokhrel, 2015; Yamamoto et al., 2011).

Lipid compounds from terrestrial sources may be identified as high molecular weight fatty acids (HFA) ( $>$ C24), as opposed to low molecular weight fatty acids (LFA) $(<\mathrm{C} 24)$ which are indicative of marine and microbial sources (Pokhrel, 2015; Yamamoto et al., 2011). Terrestrial particles may further be distinguished from those of anthropogenic sources using the Carbon Preference Index (CPI), determined as the ratio of compounds with odd to even carbon numbers. CPI values $>5$ signify an absence of anthropogenic input, whilst values decreasing down to 1 imply an increasing anthropogenic contribution. Furthermore, the average chain length (ACL) within the different 
compound groups has been utilised as evidence of specific source regions. Within the $n$-alkane group, for example, greater abundance of longer chain HFAs may indicate warm, tropical source regions, whereas a greater abundance of shorter chain HFAs would suggest more temperate source regions (Bendle et al., 2007). Calculating HFA to total organic carbon (TOC) ratios was further used to identify a tentative link between this ratio and warmer or cooler periods of global temperatures. There were, however, a number of possible explanations of higher ratio values (higher plant emissions, enhanced atmospheric transport, increased area of arid environments, and altering atmospheric transport pathways), and the idea needs refining (Bendle et al., 2007).

To date, these lipid compounds have been studied in a limited manner in snow and ice from Alaska, Greenland and lower latitude glaciers (Table 1). It will be far more challenging to detect them in Antarctica, which is further from any terrestrial sources.

\subsubsection{Secondary oxidation products}

Isoprene and terpenes are emitted from all plants including algal sources in ocean regions (Bonsang et al., 1992; Yassaa et al., 2008) and form a significant contribution to the hydrocarbon budget of the atmosphere (Sharkey et al., 2008). In particular, isoprene and monoterpenes have been measured as significant terrestrial emissions, with isoprene dominating in flux studies above Amazonian forest canopies (Kesselmeier et al., 2000; Rinne et al., 2002) and on a global level. Sesquiterpenes also contribute to terrestrial emissions, although flux and oxidation pathways of emissions are difficult to study because of their very high reactivity and lower concentrations (Fu et al., 2013). The emission of isoprene and terpenes is conditional on both heat and light, and is therefore proposed as a 'thermo-tolerance mechanism' of plants (Sharkey et al., 2008). The reactive nature of isoprene and terpenes in the atmosphere presents a limitation to the potential for long range transport from the emission site; isoprene, monoterpenes and sesquiterpenes have short chemical lifespans from a few minutes up to a few hours (Kesselmeier et al., 2000), and have not been directly observed in ice. However, the oxidation products of these compounds in both gas and aerosol phase demonstrate a greater potential for longevity in the atmosphere, and possible subsequent deposition into snow and ice further from the source region.

Isoprene and terpenes emitted by vegetation are subject to several possible degradation processes in the atmosphere, each of which may or may not result in the formation of SOA (Hallquist et al., 2009) with a multitude of secondary products forming from each primary compound. Table 2 lists a compilation of isoprene and terpene-sourced SOA compounds identified over a range of forested canopy locations and in snow samples from more remote locations. Despite this complexity, and with both degradation pathways and atmospheric concentrations still needing further study (Kroll et al., 2011), a transition in detection of some key SOA components from laboratory-confined experiments to detection in natural atmospheric samples, as well as in some surface snow and ice core studies, provides promising results for use of SOA constituents as climate markers (Fu et al., 2009; Fu et al., 2016; Pokhrel et al., 2016).

Isoprene has been identified as the largest non-methane VOC emission globally, at $\sim 600 \mathrm{Gt} / \mathrm{yr}$ (Guenther et al., 2006). Thus, even a very small percentage of VOC to SOA transformation rates could be significant in the total particulate organic matter budget of the atmosphere (e.g. $6 \mathrm{Gt} / \mathrm{yr}$ at only 1\% yield) (Carlton et al., 2009). Claeys et al. (2004a) first recognised two isoprene oxidation products, 2-methylthreitol and 2-methylerythritol, in Amazonian air samples, bolstered by the association of two gas-phase products of the oxidation process, methacrylic acid and methacrolein, providing a reaction-pathway linking isoprene and the identified SOA composition (Claeys et al., 2004b). It was later shown by Xia and Hopke (2006) that these compounds demonstrate the same 
seasonal cycle (peak concentrations during summer) as isoprene in forests in the north-eastern United States. The compounds have now been identified in a number of forest-canopy aerosol samples (e.g. Finland (Kourtchev et al., 2005) and Hungary (Ion et al., 2005), and demonstrate the important contribution of isoprene oxidation products to total atmospheric SOA concentrations. However, highly variable lifetimes for these secondary compounds have been suggested (Noziere et al., 2015), which may limit the number of compounds available for consideration.

Methylthreitol (an isoprene SOA marker), pinic acid and pinonic acid (monoterpene SOA markers) were estimated to have short lifetimes of only 0.2 days by Noziere et al. (2015), clearly limiting transportation to high latitudes where transport to polar regions may require days. Others, such as MBTCA (3-methyl-1,2,3-butanetricarboxylic acid as a monoterpene SOA marker), nocaryophyllonic acid, caryophyllinic acid and nocaryophyllinic acid (sesquiterpene SOA markers), were estimated to have lifetimes up to 10 days. These values are highly uncertain but in general circulation models; with a review of 31 such models by Tsigaridis et al. (2014) finding an average range of SOA atmospheric lifetimes of 2.4-15 days. To further add to this uncertainty, Hu et al. (2013) identified both pinic acid and MBTCA in high latitude samples of atmospheric aerosol, of which a significant contribution to the total concentrations were identified as terrestrially sourced compounds based on atmospheric transport pathway reconstruction for the supplying air masses. More substantially, isoprene and monoterpene oxidation products, including many of those products with proposed short lifetimes of less than 0.2 days, have also been identified in an Alaskan ice core dating back 350 years. For example, Pokhrel et al. (2016) identified a number of terrestrial and marine sourced SOA compounds within the ice samples (Figure 1a), using atmospheric transport pathway reconstruction to determine the compounds' source region. Thus, these compounds demonstrate not only the atmospheric transport and deposition of SOA with terrestrial sources, but also the persistence of these compounds to older ice layers. Many of the observed concentration changes were correlated with Northern Hemisphere temperature fluctuations using a combination of compound groups as well as individual compounds for comparisons (Pokhrel et al., 2016). This observation suggests also that lifetime of these compounds in the particle phase may be longer than estimated, perhaps because SOA particles may have low viscosities limiting uptake and diffusion of oxidants (Virtanen et al., 2010). If the study of these compounds is extended to Antarctica, it will be necessary to distinguish compounds with mainly terrestrial sources from those with mainly marine origins. One method is to test for a temporal correlation between the organic markers of interest and uniquely terrestrial molecules, such as the biomass burning marker levoglucosan, or to compare the results against uniquely marine emissions such as MSA, an approach used by Fu et al. (2013).

While there is still much to be investigated regarding SOA compound characteristics, their detection in natural samples in high latitude regions seems to suggest the potential for using these compounds as biomarkers in ice. Furthermore, the ever-expanding number of identified monoterpene oxidation products, e.g. at least 24 monoterpene-derived organic compounds identified above a boreal forest in Hyytiala, Finland (Kourtchev et al., 2013) provides an ever-increasing scope of promising marker compounds, of which any number may have sufficient lifetimes allowing transport and deposition to polar snow.

The groups of compounds discussed here offer excellent potential as biomarkers in ice cores. In the northern hemisphere (Greenland), multi-compound studies could, in conjunction with broad determination of their source regions (for example, terrestrial versus marine), allow investigation of past changes in the extent and climate of boreal forests. The same application has yet to be 
thoroughly tested for the southern hemisphere, where the compounds may be expected in even lower concentrations.

\subsection{Indicators of Biomass Burning}

Biomass burning is a special case of terrestrial emissions that has received considerable attention. Again, there is interest in quantifying shifts in biomass burning due both to climatic variations and anthropogenic activity. Much of the literature about biomass burning records in ice cores is based on inorganic or small organic molecules that have multiple sources but whose spikes are considered to be indicative of biomass burning. Legrand et al. (2016) and Rubino et al. (2016) recently reviewed these indicators and therefore we will not discuss them here. Black carbon, emitted during incomplete combustion of fossil fuel and biomass in both natural and anthropogenic fires, is not discussed in this review as it is not an organic chemical. Organic molecules can provide more specific markers for burning, and in some cases for the type of material being burnt. However, the episodic nature of burning events poses a challenge when examining changes in biomass burning through time.

Methane and carbon dioxide are important greenhouse gases emitted from a wide range of natural and anthropogenic sources. The isotopic ratio of atmospheric gases, such as methane and carbon monoxide, in Antarctic (Ferretti et al., 2005; Wang et al., 2010) and Arctic (Sapart et al., 2012; Wang et al., 2012) ice cores can be used as a fire proxy. These are also not discussed in this review, which focusses on organic material found in the snow/ice phase.

Many potential proxies of past fire activity are found in polar snow. The majority of these tracers are directly produced and volatilised during vegetation combustion (e.g. polycyclic aromatic hydrocarbons, black carbon) or as partially combusted biological material (e.g. resin acids, anhydro sugars) (Conedera et al., 2009). Biomass is a biopolymer mainly formed by cellulose, hemicellulose, lignin and fillers (Simoneit, 2002). Cellulose is the main constituent $(\sim 30 \%)$ of woody tissue, where its structure of long linear chains of D-glucose monomers is responsible for the structural strength of wood. Hemicellulose is a more complex mixture of polysaccharides derived from glucose, mannose, galactose, xylose and arabinose and is less abundant than cellulose in the woody tissue. Lignin is derived from the polymerisation of $p$-cumaryl, conyferyl and sinapyl alcohols. Thus, the structure of this biopolymer mainly contains anisyl (phenols), guaiacyl (methoxy-phenols) and syringyl (dimethoxy-phenols) nuclei, which are released during lignin pyrolysis (Simoneit, 2002).

Fire products are first released into the atmosphere and may then be transported to polar regions. Deep convection, generated by sensible heat released during fires, rapidly lifts the smoke plumes and injects pyroproducts into the atmosphere. Biomass burning plumes from forest fires can reach the upper troposphere and lower stratosphere, where the atmospheric lifetimes and the transport efficiency of aerosols are greater than near the surface (Damoah et al., 2004; Dentener et al., 2006; Hodzic et al., 2007; Trentmann et al., 2006). Nonetheless biomass burning plumes are often relatively short lived. This timing creates the complication that individual fires may be recorded at one location (for example in Greenland), but may not be recorded at others, either because the plume did not pass over both sites, or because there was no snowfall during the passage of the plume. Biomass burning signatures in ice are therefore best treated as a statistical sampling of burning rather than a faithful one to one record.

Some biomass burning proxies are specific as they are produced solely from biomass burning, e.g. monosaccharide anhydrides, but other proxies have multiple potential sources other than vegetation 
fires (e.g. coal burning or biogenic emissions). Here we focus on specific organic markers and how 534 combinations of markers can give additional information.

\subsubsection{Monosaccharide Anhydrides}

The most abundant monosaccharide anhydrides are levoglucosan and its isomers mannosan and galactosan which are specific proxies for vegetation combustion products (Gambaro et al., 2008; Simoneit, 2002; Zennaro et al., 2014). Levoglucosan (1,6-anhydro- $\beta$-D-glucopyranose) is a monosaccharide anhydride which is released only during the pyrolysis of cellulose at temperatures $>300^{\circ} \mathrm{C}$ (Gambaro et al., 2008; Simoneit, 2002). Galactosan and mannosan are released into the atmosphere during the pyrolysis of hemicellulose (Simoneit, 2002). The ratio between levoglucosan and its isomers may help to differentiate contribution of different fuel loads (i.e. lignite, angiosperms, gymnosperms) to the biomass burning signature detected in environmental samples (Engling et al., 2006; Fabbri et al., 2009). These ratios were utilised by Kirchgeorg et al. (2014) in sediment samples and in ice samples from the Ushkovsky, Kamchatka Peninsula, ice core (Kawamura et al., 2012), but no attempts exist in polar ice core samples.

Levoglucosan may be oxidised by $\cdot \mathrm{OH}$ in the gas phase (Hennigan et al., 2010) and in atmospheric water droplets (Hoffmann et al., 2010), resulting in an atmospheric lifetime on the order of days to a few weeks (Fraser and Lakshmanan, 2000; Hennigan et al., 2010; Ramanathan and Carmichael, 2008). Levoglucosan, therefore, is a suitable tracer for the quantification of fire activity even to remote locations due to its high concentration in vegetation fire plumes (Fraser and Lakshmanan, 2000; Holmes and Petrucci, 2006, 2007; Kehrwald et al., 2012; Zennaro et al., 2014). Kehrwald et al. (2012) demonstrated the applicability of the levoglucosan analyses to reconstruct past fire activity in Greenland snow pits with a known fire signature in August 1994 caused by biomass burning plumes originating in Canada and transported eastward to Greenland within a matter of days.

Zennaro et al. (2014) reconstructed fire activity during the past 2 millennia from analyses of levoglucosan, black carbon and ammonium in the North Greenland Eemian Ice Drilling (NEEM) ice core (Figure 1b). All three markers simultaneously recorded some fire events over the past 2,000 years, thus demonstrating the applicability of these markers in recording intense vegetation fires. Combining specific biomass burning tracers (i.e. levoglucosan and vanillic acid (see next section)) and black carbon analyses helps distinguish between anthropogenic activities such as fossil fuel combustion and biomass burning (McConnell et al., 2007; Zennaro et al., 2014). However, the lack of strong correlations between levoglucosan and black carbon in the NEEM ice core over the preindustrial era suggests that differences in emission, atmospheric stability and transport must be carefully evaluated when comparing different biomass burning proxies (Zennaro et al., 2014).

\subsubsection{Lignin and conifer resin pyroproducts}

Lignin is an important constituent of vegetation, and consists of a more variable and complicated structure than cellulose. Burning lignin releases a wide variety of compounds (Simoneit, 2002), and in particular methoxy- and dimethoxy-phenols which can be detected in Antarctic aerosols (Zangrando et al., 2013). Vanillic acid is a methoxy phenolic acid and it is one of the most abundant products of conifer lignin combustion, and thus is a specific marker for conifer combustion (Simoneit, 2002). McConnell et al. (2007) used black carbon and vanillic acid measurements along the D4, Greenland, ice core to discriminate natural and anthropogenic origins of black carbon reaching Greenland over the past two centuries. McConnell et al. (2007) concluded that the major source of preindustrial black carbon to Greenland was conifer combustion. 
Specific tracers for biomass burning, including phenolic compounds such as vanillic acid (pyrolysis product of conifers), p-hydroxybenzoic (specific marker of grass combustion), dehydroabietic acid (specific marker of conifer resin combustion) and levoglucosan were quantified in high and midlatitude ice cores from the Kamchatka Peninsula in northeast Siberia (Kawamura et al., 2012). However, determination of the type of burned biomass based on the presence of dehydroabietic acid and levoglucosan gave different results from those suggested by ratios between levoglucosan and its isomers (Kawamura et al., 2012), possibly due to different atmospheric lifetimes and natural abundance of the tracers. The largest peaks of $p$-hydroxybenzoic and vanillic acid are coeval with those of levoglucosan, suggesting that similar geographic sources, as well as similar long-range transport paths apply to each.

\subsubsection{Polycyclic Aromatic Hydrocarbons (PAHs)}

PAHs are produced by both biomass burning and fossil fuel burning (Macdonald et al., 2000 and references therein) (see also 3.4.3). The ratio of specific PAHs released during vegetation combustion may help identify samples containing forest fire signatures (Li et al., 2011; Masclet et al., 2000; Slater et al., 2002). In addition, burning vegetation produces carbon particles and gases containing "modern" levels of ${ }^{14} \mathrm{C}$, while compounds from fossil fuel combustion do not contain the heavy carbon isotope (Slater et al., 2002). Combining PAH ratios with black carbon concentrations and isotopic ratios of greenhouse gases can help differentiate biomass sources from anthropogenic sources.

One of the most specific PAHs is retene, a PAH released during boreal forest fires. Fluoranthene and pyrene, the two most abundant PAHs in superficial Greenland snow, are generally associated with vehicular, industrial and biomass combustion including from household heating resulting in seasonally-varying polar concentrations (Masclet et al., 2000; Slater et al., 2002). Other PAHs (i.e. benzo[ghi]-perylene, benzo[e]pyrene) are mainly released by traffic sources (Li et al., 2011; Masclet et al., 2000; Nielsen, 1996). Therefore, correlations between pyrene + fluoranthene and sulfate indicate a common anthropogenic origin. The simultaneous deposition of retene and ammonium indicate common boreal conifer fire sources, thus confirming these PAHs as good tracers for biomass burning events (Masclet et al., 2000).

The difference in ${ }^{14} \mathrm{C}$ isotopic composition between woody and fossil fuel combustion identified sources of combustion aerosols transported to Greenland in 1994 and 1995 (Currie et al., 1998). Slater et al. (2002) combined radiocarbon measurements in elemental carbon and PAHs at Summit, Greenland to differentiate between fossil fuel and biomass combustion contributions in the same Greenland ice sample used by Currie et al. (1998). However, high errors (23\%) and large sample sizes $(1 \mathrm{~kg})$ for the radiocarbon measurements make this approach for biomass burning detection difficult to apply routinely to ice core samples.

\subsubsection{Sources of biomass burning plumes reaching polar ice cores}

Generally, all of the fire reconstructions based on the chemical analyses of Greenland ice refer to boreal North America as the most important geographical origin source of the biomass burning plumes (Taylor et al., 1996). Zennaro et al. (2014) suggested that Central Asian forest fires may also be an important contributor to fire products reaching northwest Greenland due to the observations of peak fire proxy concentrations in the NEEM ice core during the most severe Central Asian droughts of the last millennium. Source regions for biomass burning material reaching Greenland most likely moved between the glacial and interglacial period (Zennaro et al., 2015). For example, Siberian and Canadian boreal forests are likely the main sources in the Northern 
621 Hemisphere of biomass burning products reaching Greenland (Zennaro et al., 2014), and ice cover will have removed much of this source in the last glacial period.

623 During the glacial-interglacial transition, source regions for biomass burning in the Southern Hemisphere probably remained the same as modern sources (De Angelis et al., 2012). The closest possible biomass burning source regions to Antarctica are South America, Australia and Southern Africa. Very little is known regarding the origin of biomass burning plumes reaching Antarctica over centennial or longer timescales, especially as these timescales are dependent upon changing fuel loads, circulation patterns and the atmospheric lifetime of pyrotracers. However, radiogenic isotope analyses ( $\mathrm{Sr}, \mathrm{Nd}$ and $\mathrm{Pb}$ isotopes) demonstrate that the majority of dust in Antarctica comes from South America over glacial-interglacial timescales, and particularly from Southern South America regions such as Patagonia (Delmonte et al., 2008; Marino et al., 2008; Vallelonga et al., 2010). Australia is also a possible aerosol source, especially during warm periods (Bory et al., 2010; Marino et al., 2008; Siggaard-Andersen et al., 2007; Vallelonga et al., 2010). For these distant sources in South America, Africa and Australia, it is necessary to consider both changes in biomass burning locations, and possible increases in transport efficiency and lifetime (due to reduced precipitation) when discussing glacial-interglacial record of past fire activity in Antarctic ice cores.

\subsection{Indicators of Marine Biogenic Activity}

The marine biosphere is also a source of organic emissions (Table 1). Many of the molecules produced in the ocean are recorded, for example, in marine sediments, but are unlikely to be emitted to the atmosphere in any significant quantity. However, a number of gases are emitted and subsequently oxidised to form SOA, and organic particles are also mobilised from the sea surface. Sea spray -derived aerosol particles are composed of sea salt, which is enriched with organic matter when the sea surface is characterised by high concentrations of biogenic organic matter (O'Dowd et al., 2004).

Primary organic aerosol particles are generated via wind driven bubble bursting processes, related to breaking wave and near-surface wind properties in the sea surface microlayer (SML). The SML, defined as the top $1000 \mu \mathrm{m}$ of the ocean, is the boundary between the atmosphere and the ocean and has distinct physiochemical and biological properties that differ from the underlying waters (Wurl et al., 2017). Formed by a complex mixture of carbohydrates, proteins and lipids the enriched biofilm is a potential site for enrichment of hydrophobic organic compounds (Stortini et al., 2009), such as pesticides and marine pollutants which accumulate in the SML (Wurl and Obbard, 2004).

Marine aerosols contribute significantly to the global aerosol budget. Given that Antarctica and, to a lesser extent Greenland, are surrounded by ocean, even relatively small emissions can be a dominant source of some organic molecules to the ice sheet due to the proximity of the source region. Ice core measurements of selected organics have the potential to reveal the impact of climate on marine biogenic productivity, to assess sea ice extent, and to describe the strength of winds that might mobilise material from the sea surface. Despite considerable advances in our understanding of marine organic aerosols in recent years, the formation and sources remain poorly constrained. Here we discuss the marine organic compounds identified in snow or ice samples and the most promising marine aerosol markers not yet investigated in ice.

\subsubsection{Primary emissions}

The primary organic aerosols produced from bubble bursting typically contain homologous series of oxohydroxy- or methoxy- branched fatty acids and mono-, di- and tricarboxylic acids, monoterpenes and sugars (Schmitt-Kopplin et al., 2012) together with bacteria, fragments of marine 
organisms and secretions of algae (Leck and Bigg, 2005). Unsaturated fatty acids such as oleic acid $\left(\mathrm{C}_{18: 1}\right)$, a major constituent of cell membranes in marine phytoplankton (especially diatoms), are abundant in the marine environment and dominate the sea surface micro layer (Hardy, 1982; Mochida et al., 2002).

Field and laboratory studies in the North Atlantic region have demonstrated that the fraction of organic matter in the submicrometer marine aerosol is higher during periods of high biological activity, such as phytoplankton blooms (O'Dowd et al., 2004). During the winter period, when biological activity is at its lowest, the organic fraction is greatly reduced. The seasonal surface-layer enrichment of organic matter, expected to be of biogenic origin such as lipids, proteinaceous material and humic substances, can also be observed by SeaWiFS remote sensing as increased chlorophyll concentrations.

In general, unsaturated fatty acids are easily decomposed during long-range transport or may be photochemically depleted (Mochida et al., 2002; Rontani et al., 2012). However, fatty acids in polar ice have been used as proxies for past changes in marine and terrestrial emission on multidecadal to centennial time scales. Oleic acid, and other unsaturated lower molecular weight fatty acids, have been detected as major species in ice cores from Greenland (Kawamura et al., 1996) and Alaska (Pokhrel et al., 2015) confirming that marine organic matter can be transported considerable distances in contrast to assumptions that the lifetime of these species is too short. The presence of fatty acids is largely unexplored in Antarctica but could potentially provide valuable indicators of Southern Ocean marine biogenic activity or atmospheric circulation, providing we understand both the biogenic activity at the source (marine boundary layer) and the physical processes responsible for their transport such as wind strength and transport pathways.

\subsubsection{Secondary oxidation products}

The best understood SOA component of marine aerosol is methanesulfonate or methanesulfonic acid (MSA), the oxidation product of dimethylsulfide (DMS), and the precursor compound dimethylsulfoniopropionate (DMSP) produced by phytoplankton. MSA was also one of the first organic aerosol components detected in polar ice cores (Legrand et al., 1997; Saltzman et al., 1997; Wolff et al., 2006). DMS and DMSP production in the Southern Ocean is highest within the sea ice zone, produced primarily by phytoplankton species associated with sea ice, or perhaps with sea ice retreat (Curran and Jones, 2000). When DMS oxidises in the atmosphere it creates sulfate and MSA. Sulfate has multiple possible sources including sea salts and volcanic activity while marine biological activity is the only known source of MSA in the Antarctic region. Thus, it was hypothesised that MSA preserved in ice cores could be used to reconstruct past marine productivity and sea ice coverage.

Statistically significant correlations between MSA and sea ice extent (Figure 1c) have been observed at a number of coastal sites around Antarctica (Abram et al., 2010; Curran et al., 2003; Foster et al., 2006; Thomas and Abram, 2016; Welch et al., 1993), where high MSA represents extensive winter sea ice extent. A greater sea ice extent leads to a larger area of sea ice breakup during the spring and summer, allowing for greater biological activity and DMS production. However, a converse relationship has also been observed with MSA from sites in West Antarctica, where elevated MSA represents summer productivity within the sea ice zone and the presence of open water polynyas (Criscitiello et al., 2013; Rhodes et al., 2009; Sinclair et al., 2014). MSA is less studied in the Arctic although MSA from coastal Svalbard has been related to summer sea ice extent (O'Dwyer et al., 2000). Satellite-derived connections between Arctic ice edge and algal blooms (Perrette et al., 2011) and atmospheric measurements of DMS (Sharma et al., 2012) show 
promise for MSA as a proxy of past sea ice conditions. The amount of MSA preserved in an ice core reflects not only changes in the amount of DMS produced within the sea ice zone but also the transport, deposition and preservation of MSA on the ice sheet (Abram et al., 2007; Becagli et al., 2009; Fundel et al., 2006; Preunkert et al., 2008) and thus careful site examination and calibration of MSA with satellite sea ice data is essential.

Isoprene SOA tracers are believed to be derived from dual (marine and terrestrial) biogenic sources oxidation is considerably less than the oxidation products of DMS and marine amines (Vignati et al., 2010 and references therein). Globally, terrestrial vegetation is a major source of isoprene emissions, while marine vegetation is only a minor source of isoprene emissions (Hallquist et al., 2009). However, the air masses reaching the Antarctic have a strong oceanic influence while terrestrial sources have less of an influence due to their distance from the continent.

A number of other SOA tracers have been quantified in the marine environment, which have potential as marine indicators for biogenic change. Dimethyl and diethylammonium salts $\left(\mathrm{DMA}^{+}\right.$ and $\left.\mathrm{DEA}^{+}\right)$, believed to be of biogenic origin, and produced through the reaction of gaseous amines with sulfuric acid or acidic sulfates (Facchini et al., 2008). They were identified over the North Atlantic (Facchini et al., 2008) and over the Pacific Ocean (Sorooshian et al., 2009) and are found to be the most abundant organic species, second only to MSA, detected in fine marine particles. Like MSA, $\mathrm{DMA}^{+}$and $\mathrm{DEA}^{+}$have no anthropogenic origin and exhibit a clear seasonality, making them potentially a viable indicator of marine biogenic activity, but as yet they have not been measured in polar ice.

Azelaic acid, a product from the photochemical transformation of unsaturated fatty acids, has been proposed as a proxy of marine biogenic activity. Equally, low molecular weight dicarboxylic acids, such as succinic, malonic and oxalic acids, have been related to photochemical oxidation of marine biogenic compounds and especially oxidation of unsaturated fatty acids, which are enriched in the SML (Kawamura et al., 2001). Concerning oxalate, biomass burning and fossil fuel combustion are additional sources (Kawamura et al., 2001; Legrand and De Angelis, 1996; Müller-Tautges et al., 2016). Diagnostic ratios of dicarboxylic acids can be used to gather more information on the possible emission sources and atmospheric processing (Kawamura and Bikkina, 2016). Higher $\mathrm{C}_{2} / \mathrm{C}_{4}$ were observed in tropical aerosol compared with high latitude aerosol. High $\mathrm{C}_{3} / \mathrm{C}_{4}$ were documented for marine aerosol as opposed to vehicular emissions, and linked to atmospheric aging of the air masses, as malonic acid is less stable than succinic acid. Conversely, higher $\mathrm{C}_{6} / \mathrm{C}_{9}$ were observed for anthropogenically influenced continental aerosol compared with oceanic air masses. Measurements in an ice core from Site-J, Greenland, showed correlation between dicarboxylic acids and sea ice advance/retreat. Their concentrations are additionally influenced by the oxidation capacity of the atmosphere potentially providing information on atmospheric changes due to either natural variability or anthropogenic activities (Kawamura et al., 1999). Fluctuations in oxalate concentrations showed an association with sea-to-air emission of biogenic compounds as well as Northern Hemisphere solar irradiance (Kawamura et al., 2001).

Organosulfates (sulfate esters of $\mathrm{C}_{9}-\mathrm{C}_{13}$ hydroxyl carboxylic acids) can also be considered as marine SOA tracers. They arise from the oxidation of unsaturated fatty acids derived from marine algae (Claeys et al., 2010). Organosulfates have been observed at low concentrations in the Indian Ocean and may be detectable at coastal polar locations close to sea ice algae (Grannas et al., 2006). However, organosulfates have been observed in terrestrial SOA studies from reaction of organics 
with anthropogenic $\mathrm{H}_{2} \mathrm{SO} 4$ (Surratt et al., 2007) so specificity to marine sources needs to be tested for each individual sulfate ester compound.

\subsection{Anthropogenic Emissions}

Human activity has influenced the emissions of many natural organic compounds into the atmosphere, for example through altering biomass burning rates or changing forest into cropland (or other land use changes). However, perhaps more obvious, is the introduction of new molecules into the atmosphere that were not present (or present in much smaller quantities) until human industrial manufacturing occurred. This class of new compounds includes PCBs and pesticides.

Measurements in ice cores can verify the timing of increased emissions and the effectiveness of mitigation measures. These results can also serve as essential background determinations for assessing any ecological effects observed in the polar regions themselves. The choice of chemicals to be measured is therefore based on the strength of concern over ecological and human health risks. The nature of this issue means that such molecules are of interest only in the last few decades up to about two centuries in extreme cases, and will therefore be measured only in relatively shallow cores, and often mainly in firn rather than ice.

The poles remain in the popular imagination as the final frontier of purely natural locations that are far removed from effects of human activity. In fact, the poles are regions of "minimum anthropogenic presence" (Kallenborn et al., 2013) but are not absent of human influence (Bossi et al., 2013; Chen et al., 2015; Fuoco et al., 2012; Hermanson et al., 2005; Ma et al., 2011). Transport of anthropogenically-emitted compounds from lower latitudes to the Arctic (and to a lesser extent the Antarctic) has been recognised for many decades, and is commonly referred to as Arctic Haze (e.g. Barrie et al., 1992). In addition, human presence in the polar regions is increasing with a warming climate. Declining Arctic sea ice is opening up a September Northwest Passage for shipping traffic (Laliberté et al., 2016), and mineral exploration in the Arctic has the potential to substantially alter the regional concentrations of anthropogenic aerosols (e.g. Bedini, 2011). In Antarctica, isolated research stations provide interesting case studies of the areal extent of contamination from point sources. Here we discuss the most important classes of anthropogenic organic compounds detected in polar regions and potential implications of their presence in the ice caps. One common aspect of many of these compounds is that they may be re-volatilised to the atmosphere as ice recedes in a warming climate, and therefore the potential to reintroduce phasedout compounds to the atmosphere has to be recognised.

\subsubsection{Persistent Organic Pollutants (POPs)}

POPs are primarily anthropogenic compounds that are recalcitrant to biological and chemical degradation under most environmental conditions. The persistence of these pollutants and their resistance to degradation in the environment results in their accumulation in ice, sediments, and within animal and human tissues (e.g. Andersen et al., 2015; Chen et al., 2015; Gustafsson et al., 2005). Many POPs were first synthetically produced in the mid-twentieth century as pesticides, industrial chemicals, and solvents. Due to the detrimental and far-reaching effects of POPs on human health, the Stockholm Convention on Persistent Organic Pollutants, which entered into force in 2004, restricts or bans the production and continued use of POPs (chm.pops.int; UNEP, 2004). The Stockholm Convention identified an initial "dirty dozen" of POPs (Table 3) that required an immediate cessation due to their toxicity, persistence, and noted bioaccumulation (chm.pops.int; UNEP, 2004; Table 3). The majority of the "dirty dozen" are pesticides; as pesticides are primarily used in areas with substantial agriculture, any pesticides present in polar regions arrived via longrange transport. 
As shown in Table 3, POPs, and pesticides in particular, have been detected in different Svalbard ice cores (Figure 1d) (Hermanson et al., 2005; Ruggirello et al., 2010), Antarctic glacier ice, penguins (Geisz et al., 2008), and Arctic foxes (Andersen et al., 2015) demonstrating their widespread presence reaching the most pristine areas on the planet. Organochlorine pesticides have also been reported in surface snow of East Antarctica (Kang et al., 2012; Peel, 1975) and in the Devon Island ice cap in Canada (Zhang et al., 2013). Organophosphorus pesticides have been detected in Svalbard ice, together with methyl parathion and Dieldrin (Barbante et al., 2017; Isaksson et al., 2003). POPs are among the compounds with the possibility to re-volatilise from Arctic ice back into the atmosphere (Ma et al., 2011; Wohrnschimmel et al., 2013). Adding to the importance of studying POPs, recent models demonstrate that the northward extension of arable land and the associated increase in the use of agrochemicals would double POPs concentrations in Arctic air and quadruple their concentrations in Arctic water (Wohrnschimmel et al., 2013).

\subsubsection{Polychlorinated biphenyls (PCBs)}

PCBs are anthropogenic organic substances produced and used in the 1960s and 1970s. Increasing awareness of their harmful environmental properties led to their diminished use in the 1970s and eventually their worldwide ban as part of the Stockholm Convention on POPs in 2004 (chm.pops.int; UNEP, 2004).

PCBs can arrive to the poles through long-range atmospheric transport due to their high vapour pressure, and a relatively long atmospheric lifetime of up to 30 days in the gas phase (Anderson and Hites, 1996). PCBs have also been observed in the SML in coastal Antarctic waters (Fuoco et al., 2005), where they are enriched relative to bulk sea water concentrations. PCBs are primarily removed from the atmosphere by reacting with $\cdot \mathrm{OH}$; oxidation is slower in polar areas due to low temperatures, low humidity, and low tropospheric ozone concentrations (Ruggirello et al., 2010). The lack of UV-B radiation during the polar night means that $\cdot \mathrm{OH}$ are not produced during the corresponding winter months, resulting in a longer lifetime of PCBs in polar areas than in other regions (Brönnimann et al., 2000).

PCBs are deposited on the surface by partitioning into aerosol particles and incorporation into snowfall (Garmash et al., 2013; Wania et al., 1998). Lower-chlorinated PCB congeners tend to return to the surface by dry deposition, while higher-chlorinated PCB congeners are mainly deposited by wet deposition (Steinlin et al., 2014). This difference in deposition means that the lower-chlorinated PCBs may re-volatise after deposition, and therefore may not be incorporated into the deeper glacier ice. The surface snowpack acts as a filter for the compounds where heavy PCBs may bind to fine suspended particles resulting in an enrichment of PCBs in particle layers (Pavlova et al., 2015). The higher-chlorinated PCB congeners may then be more prevalent in glacier ice (Steinlin et al., 2014). Once PCBs are incorporated into the glacier ice, they undergo a variety of processes (e.g. volatilisation and chemical transformation) before they are permanently archived, as discussed in general terms in section 2.3. In particular, they may be subject to vertical and horizontal transport within the glacier, leading to a subsequent release into meltwater (Blais et al., 2001; Schmid et al., 2011), or to surface meltwater containing dissolved PCBs that percolate through the firn where they may then refreeze at a deeper level in the glacier ice (Pavlova et al., 2015).

Similar to the other POPs polar ice caps are also increasingly becoming a source of PCBs through re-volatilisation into the atmosphere (Ma et al., 2011). Concentrations of PCBs in the Arctic steadily declined in atmospheric samples collected at Alert, Canada from 1992 to 2000 due to the restrictions on the current and future production of PCBs (Hung et al., 2005). This declining trend 
in PCB concentrations was also observed until approximately 2000 is also present in a $37 \mathrm{~m}$ ice core from Lomonosovfonna, Svalbard (Garmash et al., 2013). However, the $\mathrm{P}$ PB concentrations increased in the Lomonsovfonna ice core and remain elevated from 1998 until 2009 (Garmash et al., 2013). Back trajectories demonstrate that air masses influencing Lomonosovfonna originate in Europe and western Russia where relic PCBs from urban areas and/or incineration of older materials that contain PCBs may influence the high PCB concentrations in Svalbard over the last decade. These high PCB concentrations are consistent with model simulations and high Arctic atmospheric concentrations resulting from the revolatilisation of POPs from ice into the atmosphere due to warming temperatures (Garmash et al., 2013; Ma et al., 2011). Due to their persistence and previous entrapment in sinks such as snow and ice, atmospheric concentrations of PCBs and other POPs may continue to increase in a warming climate, where these concentrations may be especially high in polar regions.

\subsubsection{Polycyclic aromatic hydrocarbons or pseudo-POPs}

PAHs can be produced by both biomass and fossil fuel burning (see section 3.2.3). The incomplete combustion of both oil and coal release PAHs, where PAHs produced by burning crude and refined oil can be highly alkylated (Yunker and Macdonald, 1995). These alkylated PAHs may be more harmful to life than the PAHs without alkyl substitutions (Barron and Holder, 2003). While PAHs are toxic, they are only accepted as POPs under the Aarhus Protocol instead of under the Stockholm Convention, and therefore are subject to less regulation (Aarhus-Protocol, 1998).

PAHs primarily arrive to polar regions through atmospheric transport. Heavier, less-volatile PAHs travel with particles in the atmosphere, where they arrive along the same trajectories that transfer chemicals from the mid-latitudes (Barrie et al., 1992). As heavier PAHs are associated with particles, they are removed from the atmosphere by precipitation. During the Arctic winter months, PAHs may remain in the atmosphere for up to $\sim 30$ days, while the more frequent summer Arctic precipitation results in atmospheric residence times of less than a week (Macdonald et al., 2000). PAHs may re-enter the atmosphere even after they are deposited through the resuspension by winds, by the removal of sediments or snow that had covered the PAHs and associated particles, or by re-volatilising due to increased temperatures (Macdonald et al., 2000; Wania and Mackay, 1996).

Less-volatile PAHs travel with particles in the atmosphere, where they arrive along the same trajectories that transfer chemicals from the mid-latitudes (Barrie et al., 1992). As heavier PAHs are associated with particles, they are removed from the atmosphere by precipitation. During the Arctic winter months, PAHs may remain in the atmosphere for up to $\sim 30$ days, while the more frequent summer Arctic precipitation results in atmospheric residence times of less than a week (Macdonald et al., 2000). PAHs may re-enter the atmosphere even after they are deposited through the resuspension of dust or snow by winds, by the removal of sediments or snow that had covered the PAHs and associated particles, or by revolatilizing due to increased temperatures (Macdonald et al., 2000; Wania and Mackay, 1996).

PAHs from human activities are pervasive in the Arctic and Antarctic including in the seawater and air (Lohmann et al., 2009), as well as snow and ice (Masclet et al., 2000; Vecchiato et al., 2015). Innovative work examining PAHs in Arctic snow and ice cores over the past few centuries demonstrate an exponential increase in PAHs beginning in the 1930s associated with the major increase in fossil fuel burning (Jaffrezo et al., 1993; Jaffrezo et al., 1994; Kawamura et al., 1994; Masclet et al., 1995; Masclet et al., 2000). This increase in PAH concentrations is consistent across the Arctic, yet the concentrations vary by region where the Agassiz Ice Cap, Canada has the highest 
concentrations (mean of $\sim 60 \mathrm{ng} / \mathrm{L}$ with a peak concentration of $640 \mathrm{ng} / \mathrm{L}$ ), while Lomonosovfonna, Svalbard contains mid-range concentrations of $5-53 \mathrm{ng} / \mathrm{kg}$, and Greenland ice core concentrations tend to have the lowest PAH values with a maximum of only $0.5 \mathrm{ng} / \mathrm{L}$ (Vehvilainen et al., 2002 and references therein). PAH concentrations in the Lomonosovfonna ice core are characterised by a clear seasonality, with higher concentrations associated with the buildup of the wintertime Arctic Haze due to transports of chemicals/aerosols from the mid-latitudes (Macdonald et al., 2000; Vehvilainen et al., 2002 and references therein). Less is known about PAH concentrations in the Antarctic compared to the Arctic. However, the Talos Dome, Antarctica ice core demonstrates similar trends in PAH concentrations as the Arctic ice cores, where $\Sigma$ PAHs markedly increase beginning in the 1930s due to fossil fuel burning (Fuoco et al., 2012). This increase is less than in the comparable Arctic ice cores, as the Talos Dome PAH concentrations rise by $50 \%$ instead of an exponential increase observed in the Arctic (Fuoco et al., 2012). Future studies regarding the seasonality and spatial distribution of PAHs in Antarctic ice can help better compare these two locations.

\subsubsection{Emerging pollutants}

Emerging pollutants, i.e. substances that are not commonly monitored but have the potential to enter into the environment and cause ecological and/or public health effects (Geissen et al., 2015), are worth investigating in shallow cores and surface snow in polar regions to understand the extent of pollution. These can include new classes of pesticides, pharmaceuticals, disinfection by-products, wood preservation and industrial chemicals (Geissen et al., 2015) that could potentially enter into global atmospheric or marine transport. For example, little is known about Arctic concentrations of the most recent replacement pesticides, like the widely-used neonicotinoids that have dominated the insecticide market since the early 1990s and are only very recently partially being banned (Bonmatin et al., 2015; Giorio et al., 2017; Simon-Delso et al., 2015). In addition, brominated flame-retardants (BFRs), compounds that are used to slow the spread of flames in residential and commercial indoor fabrics, foams, and electronics, have been found in Arctic wildlife, lake sediments, ice and air samples (Barbante et al., 2017 and references therein).

Perfluorinated chemicals (PFCs), also known as per- and polyfluoroalkyl substances (PFASs), contain many of the same concerns as previous POPs in the fact that they are present throughout the globe, bioaccumulate, do not degrade in the environment, and can be toxic to both animals and humans (Ahrens et al., 2011; Wang et al., 2014 and references therein). Increasing evidence demonstrates that long-chain PFASs (LC PFASs) with 6 and more perfluoroalkyl carbons, and long-chain perfluoroalkyl carboxylic acids (LC PFCAs) with 7 and more perfluoroalkyl carbons are more toxic and more prone to bioaccumulate than their shorter-chained variations (Buck et al., 2011; OECD, 2013). Due to their persistence in the environment, bioaccumulation, and toxic effects, both industry and government regulators are attempting to reduce the production and release of LC PFCAs. Although these substances have been phased-out in much of Western Europe, Japan, and the United States, these chemicals are still produced in continental Asia (Wang et al., 2014).

Although PFASs and PFCAs are ubiquitous in the environment, their transport mechanisms still require further study (Armitage et al., 2009; Wang et al., 2014). PFCAs do not attach to particulate matter settling into the deep ocean, and therefore remain dissolved in water (Armitage et al., 2009; Scheringer et al., 2004). Modelling and observational studies show that PFCAs primarily arrive to the Arctic and Antarctic Oceans via marine transport (Armitage et al., 2009; Prevedouros et al., 2006; Yamashita et al., 2005). PFCAs can volatise from the ocean in more temperate locations, but 
933 the polar low temperatures and sea ice cover inhibit their volatilization once PFCAs reach the poles 934 (Wania, 2006).

935 If the continued production of PFCAs and PFASs in Asia directly emits these substances into the atmosphere, where they can then also be subject to atmospheric transport to the poles (Benskin et al., 2012). The presence of PFASs in Arctic ice cap samples suggests that atmospheric oxidation of volatile precursors is another source of PFASs to inland Arctic regions (Young et al., 2007). Consistently high atmospheric PFAS concentrations near the Antarctic Peninsula (mean 23.5 $\mathrm{pg} / \mathrm{m}^{3}$ ) are due to the supply of PFASs from new air masses, combined with decreased degradation in the polar atmosphere, and the air-snow exchange (Wang et al., 2015). The re-volatilisation of PFASs from polar snow is a source of PFASs to the atmosphere, where this source may become increasingly important under warming conditions (Wang et al., 2015). Currently, very limited studies exist that examine PFASs in Antarctic (Wang et al., 2015) and Arctic (Young et al., 2007) snow. Examining spatial transects and temporal profiles of PFASs in snow and ice would help to determine the atmospheric spread and fate in snow of these persistent toxic chemicals.

\section{Conclusions}

There is a great potential for organic aerosol compounds to be used as proxies for terrestrial biogenic emissions, past fire events of different types of biomasses, marine biogenic activity and anthropogenic activities, all further leading to the possibility of inferring temperature fluctuations, changes in sea ice and even large-scale climate variability. However, their measurement in polar ice has proved to be challenging. More research is needed to advance our understanding of compoundspecific behaviour and stability related to atmospheric and ice archive lifetimes and characterization of sources of sample contamination that may arise during drilling, and subsequent storage and transport. Specific decontamination and clean handling procedures suited for organic analysis still needs development and validation. This aspect may include installing clean rooms specifically designed for handling samples for organic analysis, avoiding plastic materials and installing appropriate filters to eliminate organic vapours.

A wide range of analytical methods have been developed to analyse specific organic compounds or important compound classes in ice cores. The majority of these methods use GC-MS and LC-MS and in general researchers can choose the method that best fits their research objectives and availability of different lab facilities and instrumentations. More research is needed in order to lower detection limits, especially for the cleaner Antarctic samples, as well as decreasing the amount of sample needed to ensure a good time resolution in the archive. Fast analytical methods and small sample volume may open up the possibility of coupling organic analysis to the continuous flow analysis systems routinely used for analysis of inorganic compounds in the ice cores.

Concerning terrestrial emissions, fatty acids, together with isoprene, monoterpene, and sesquiterpene SOA products, offer excellent potential as terrestrial biomarkers in ice cores. While detection of all individual compounds may prove challenging due to their variable reactivities, longdistance transport and long-term preservation of many of the compounds of interest was shown in snow layers well within the perimeters of the polar regions. Biomass burning is by far the most studied area in terms of available measurements of organic markers in the Arctic. Yet in this area, more studies are needed to assess atmospheric lifetimes of biomass burning markers, improve the predictability of past transport dynamics in air masses around the globe and improve analytical capabilities towards the measurement of multiple proxies with the same method and in high temporal resolution (i.e. low sample volume). Lignin pyrolysis products and resin acids show the 
potential, if coupled with measurements of levoglucosan and its isomers, to differentiate between different types of biomass being burned. Furthermore, it would be interesting to assess the possibility to use mega fire events (i.e. recorded as levoglucosan or black carbon spikes) as temporal horizons for precise ice core chronologies.

The use of marine organic aerosols in polar ice is a relatively new area of research and one that requires considerable investigation. The main problems are that marine organic aerosols are influenced not only by oceanic emissions of primary aerosols and SOA precursors, but also by continental emissions through long-range atmospheric transport. This should have less of an influence in the Antarctic, especially at coastal locations. However, careful site assessment and calibration with observational records such as satellite measurements of sea ice extent is required and may also be hindered by a lack of field measurements of marine aerosols, especially in the polar regions, limiting our understanding of the abundances of biogenic SOA in the marine boundary layer. Dimethyl and diethylammonium salts can be potentially viable indicators of marine biogenic activity, but as yet they have not been measured in polar ice. Low molecular weight dicarboxylic acids, from the oxidation of unsaturated fatty acids from primary marine emissions, have been proposed as proxies for the reconstruction of past oxidative capacity of the atmosphere (Kawamura et al., 2001).

Despite the poles, and especially Antarctica, being the most pristine regions on Earth, human influence has been recorded on both surface snow and shallow ice cores. A plethora of anthropogenic compounds have been measured in ice samples, including many pesticides, POPs, PCBs, PAHs, and PFASs, and in the local fauna. Ice cores can document the input of compounds with harmful environmental properties, bioaccumulation, and toxic effects to the polar regions, as well as the beneficial effects of mitigation measures. Additional complexity occurs since some of these compounds may be released from the archives in a warming climate by re-evaporation in the air-snow interface or re-dissolution in the ocean. Finally, research is needed to establish baseline ice core measurement and to develop robust analytical techniques to better understand the environmental spread of replacement pesticides and other emerging pollutants introduced in the environment by human activities.

\section{Acknowledgments}

EW is supported by a Royal Society professorship. The research leading to these results has received funding from the European Union's Seventh Framework Programme ("Ideas" Specific Programme, ERC Advanced and Consolidator Grants) under grant agreement 267696 

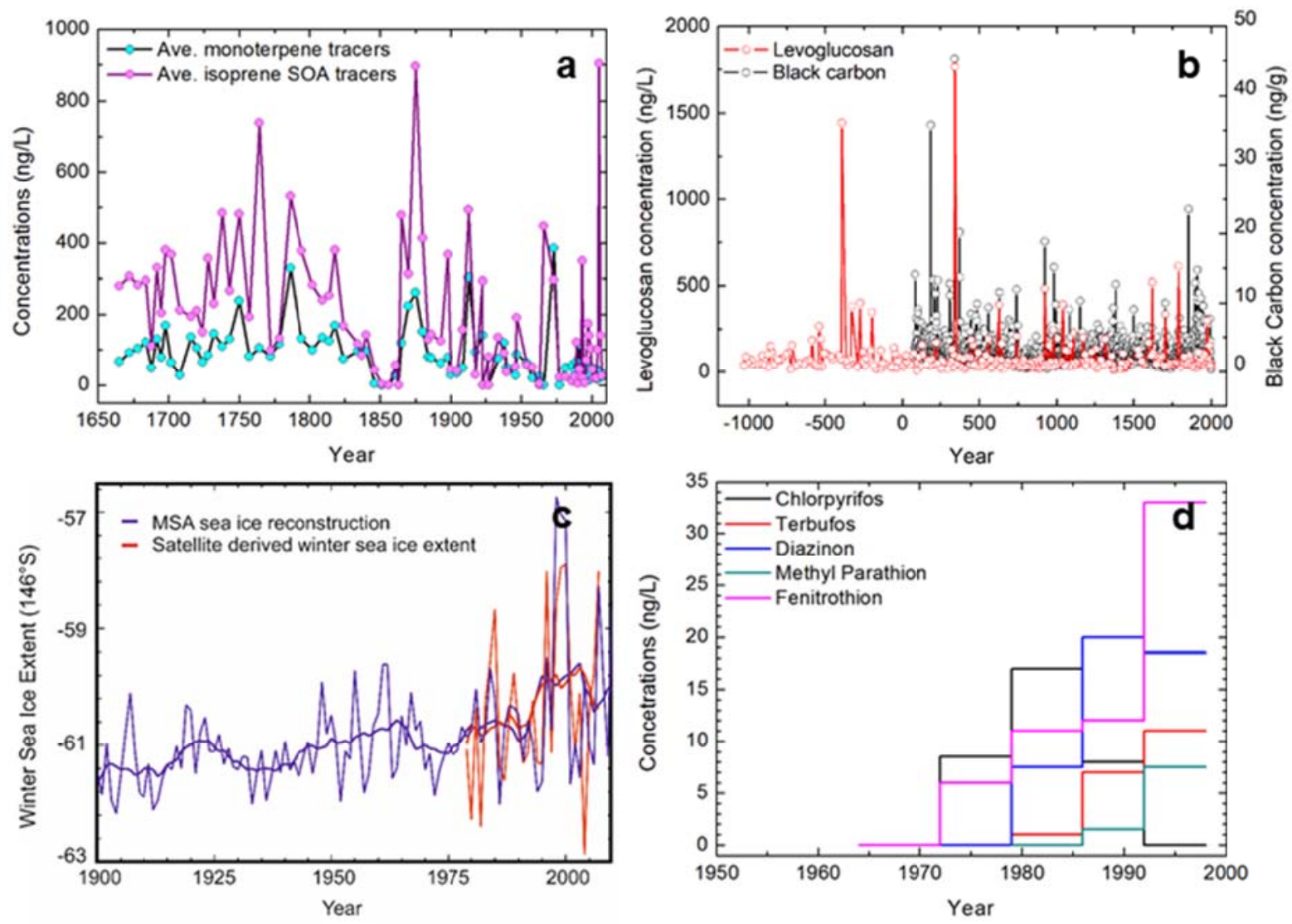

1013 Figure 1. (a) Average concentration changes of monoterpene tracers and total annual average concentrations of isoprene SOA tracers in the Alaska ice core records collected from Aurora peak (Pokhrel et al., 2016); (b) levoglucosan concentration profile measured in the deep NEEM core and black carbon concentration profile measured in the NEEM2011-S1 ice core (Zennaro et al., 2014); (c) winter sea ice reconstruction derived from MSA and satellite derived winter sea ice extent for the Amundsen-Ross sea (adapted from Thomas and Abram (2016)); (d) concentration trends of five

1018 organophosphorus compounds at Austfonna, Svalbard (reproduced from Hermanson et al. (2005)). 
1020 Table 1. Analytical methods used and method performances for the measurement of terrestrial, marine, biomass burning and anthropogenic markers in polar ice and snow.

\begin{tabular}{|c|c|c|c|c|c|c|c|c|c|}
\hline Compounds & $\begin{array}{c}\text { Sample } \\
\text { preparation }\end{array}$ & Technique & $\begin{array}{c}\begin{array}{c}\text { Amount } \\
\text { used } \\
\text { for analysis }\end{array} \\
\end{array}$ & Recovery & $\begin{array}{l}\text { Method } \\
\text { LOD }^{\mathbf{a}}\end{array}$ & $\begin{array}{c}\text { Concentration } \\
\text { range }\end{array}$ & Archive/Sample ${ }^{b}$ & Age/depth & References $^{c}$ \\
\hline \multicolumn{10}{|c|}{ Anthropogenic markers } \\
\hline Pesticides & SPE & GC-MS & $11 \mathrm{~L}$ & $80 \%$ & $1-84 \mathrm{pg} / \mathrm{L}$ & $1.1-87.0 \mathrm{ng} / \mathrm{L}$ & $\begin{array}{c}\text { Austfonna ice core, } \\
\text { Svalbard }\end{array}$ & $\begin{array}{c}70 \mathrm{~m} \\
1906-1998 \mathrm{AD}\end{array}$ & $\begin{array}{l}\text { (Muir et al., 2004) } \\
\text { (Hermanson et al., } \\
\text { 2005) }\end{array}$ \\
\hline Pesticides & SPE & GC-MS & $11-15 \mathrm{~L}$ & $80 \%$ & $1-84 \mathrm{pg} / \mathrm{L}$ & $0.08-77.6 \mathrm{ng} / \mathrm{L}$ & $\begin{array}{l}\text { Holtedahlfonna ice } \\
\text { core, Svalbard }\end{array}$ & 1953-2005AD & $\begin{array}{l}\text { (Muir et al., 2004) } \\
\text { (Ruggirello et al., } \\
\text { 2010) }\end{array}$ \\
\hline Pesticides & SPE & GC-MS & $\sim 4.5 \mathrm{~L}$ & & $0.04-2.5 \mathrm{pg} / \mathrm{L}$ & up to $8.91 \mathrm{pg} / \mathrm{L}$ & $\begin{array}{l}\text { Sea ice and snow, } \\
\text { Antarctica }\end{array}$ & Sept-Oct 2001 & $\begin{array}{l}\text { (Dickhut et al., } \\
\text { 2005) }\end{array}$ \\
\hline Pesticides & $\begin{array}{c}\text { LLE } \\
\text { Fractionation }\end{array}$ & $\begin{array}{l}\text { GC-FID and } \\
\text { GC-ECD }\end{array}$ & $9 \mathrm{~L}$ & $>70 \%$ & $10-30 \mathrm{pg} / \mathrm{L}$ & $0-870 \mathrm{pg} / \mathrm{L}$ & $\begin{array}{c}\text { pack ice, Terra } \\
\text { Nova Bay, } \\
\text { Antarctica }\end{array}$ & 1988/1989 AD & $\begin{array}{c}\text { (Desideri et al., } \\
\text { 1991) }\end{array}$ \\
\hline $\begin{array}{l}\text { Pesticides and } \\
\text { PCBs }\end{array}$ & LLE & GC-ECNI-MS & $1 \mathrm{~L}$ & $64-310 \%$ & $1-10 \mathrm{ng} / \mathrm{L}$ & $0-80 \mathrm{ng} / \mathrm{L}$ & $\begin{array}{c}\text { arctic snow/sea ice, } \\
\text { Alaska }\end{array}$ & $\begin{array}{c}\text { 1995-1996 annual } \\
\text { snowfall }\end{array}$ & $\begin{array}{c}\text { (Garbarino et al., } \\
\text { 2002) }\end{array}$ \\
\hline PCBs & $\begin{array}{c}\text { LLE in GLVE }{ }^{\mathrm{d}} \\
\text { Solvent Evaporation } \\
\text { Fractionation }\end{array}$ & GC-ECD & $14.8-20 \mathrm{~L}$ & $46-125 \%$ & & $100-4000 \mathrm{pg} / \mathrm{L}$ & ice cap, Canada & 1963-1993AD & $\begin{array}{c}\text { (Gregor et al., } \\
1995)\end{array}$ \\
\hline PCBs & $\begin{array}{l}\text { LLE } \\
\text { Evaporation to } 1 \mathrm{~mL}\end{array}$ & GC-MS & $7 \mathrm{~L}$ & $59-85 \%$ & $2-6 \mathrm{pg} / \mathrm{L}$ & $\begin{array}{c}<0.2 \mathrm{ng} / \mathrm{L} \text { as } \\
\Sigma \mathrm{PCBs}\end{array}$ & $\begin{array}{c}\text { firn/snow cores, } \\
\text { Talos Dome, } \\
\text { Antarctica }\end{array}$ & $1600-2000 \mathrm{AD}$ & $\begin{array}{c}\text { (Fuoco et al., } \\
\text { 2012) }\end{array}$ \\
\hline PCBs & SPE & GC-MS & $15-20 \mathrm{~L}$ & $59-130 \%$ & $\begin{array}{c}\mathrm{pg} / \mathrm{samples} \\
\text { (blank=LOD) }\end{array}$ & & $\begin{array}{l}\text { snow and ice core, } \\
\text { Lomonosovfonna } \\
\text { Glacier (Svalbard) }\end{array}$ & $\begin{array}{c}37 \mathrm{~m} \\
1957-2009 \mathrm{AD}\end{array}$ & $\begin{array}{l}\text { (Garmash et al., } \\
\text { 2013) }\end{array}$ \\
\hline
\end{tabular}




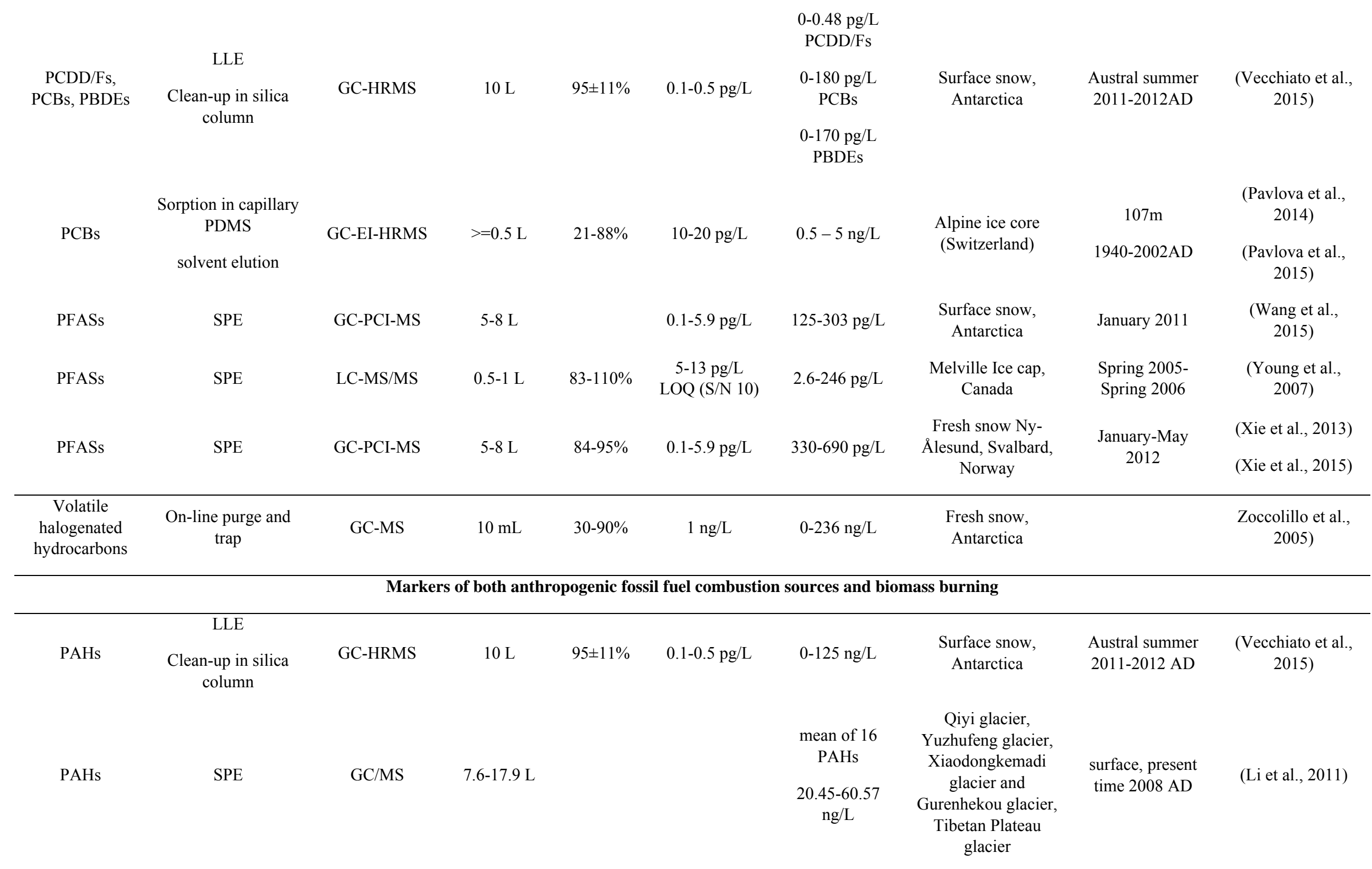




\begin{tabular}{|c|c|c|c|c|c|c|c|c|c|}
\hline PAHs & $\begin{array}{l}\text { filtration, solvent } \\
\text { extraction, filtration, } \\
\text { evaporation }\end{array}$ & $\begin{array}{c}\text { HPLC- } \\
\text { fluorescence }\end{array}$ & $5-12 \mathrm{~L}$ & & $\begin{array}{c}20 \mathrm{ng} / \mathrm{L} \\
\text { (lower calibr. } \\
\text { standard) }\end{array}$ & $\begin{array}{l}\sum 14-\mathrm{PAHs} 100 \\
-10,630 \mathrm{ng} / \mathrm{L}\end{array}$ & $\begin{array}{c}\text { ATM station, } \\
\text { Summit, Greenland }\end{array}$ & $\begin{array}{c}5 \mathrm{~m} \\
1989-1993 \mathrm{AD}\end{array}$ & $\begin{array}{l}\text { (Masclet et al., } \\
\text { 2000) }\end{array}$ \\
\hline PAHs & filtration, essication & $\mathrm{SFE}-\mathrm{GC} / \mathrm{MS}^{\mathrm{e}}$ & $100-200 \mathrm{~mL}$ & & & $\begin{array}{l}\sum 10 \text { PAHs } 3130 \\
-21,083 \mathrm{ng} / \mathrm{L}\end{array}$ & GISP2, Greenland & $\begin{array}{c}3 \text { m snowpit } \\
\text { 1994-1995 AD }\end{array}$ & $\begin{array}{l}\text { (Slater et al., } \\
\text { 2002) }\end{array}$ \\
\hline PAHs & filtration, essication & SFE-GC/MS ${ }^{\mathrm{e}}$ & $120 \mathrm{~mL}$ & & & $8-18 \mathrm{pg}$ & GISP2, Greenland & August 1994 & $\begin{array}{l}\text { (Currie et al., } \\
\text { 1998) }\end{array}$ \\
\hline PAHs & $\begin{array}{l}\text { Filtration, soxhlet, } \\
\text { evaporation for } \\
\text { insoluble material; } \\
\text { SPE (after filtration) } \\
\text { for soluble PAH }\end{array}$ & $\begin{array}{c}\text { HPLC- } \\
\text { fluorescence }\end{array}$ & $\sim 16 \mathrm{~L}$ & & $\mathrm{pg} / \mathrm{L}$ & $\begin{array}{c}\Sigma \mathrm{PAH} \\
598-2367 \mathrm{pg} / \mathrm{L} \\
\text { (insoluble); } \\
<\text { LOD } \\
\text { (soluble) }\end{array}$ & $\begin{array}{c}\text { Insoluble PM } \\
\text { Greenland ice } \\
\text { Summit, Greenland }\end{array}$ & 1988-1991 AD & $\begin{array}{c}\text { (Jaffrezo et al., } \\
1994)\end{array}$ \\
\hline PAHs & $\begin{array}{c}\text { SPME } \\
\text { Thermal desorption } \\
\text { in GC }\end{array}$ & GC-MS & $30 \mathrm{~mL}$ & $\begin{array}{l}65->80 \% \\
<20 \% \text { for } \\
4-6 \text { ring } \\
\text { PAHs }\end{array}$ & $\begin{array}{c}0.13-5.14 \\
\mathrm{ng} / \mathrm{L}\end{array}$ & $\begin{array}{l}<35 \mathrm{ng} / \mathrm{L} \\
(\Sigma \mathrm{PAH})\end{array}$ & $\begin{array}{l}\text { Firn, Ekström } \\
\text { Shelf Ice in the } \\
\text { Weddell Sea, } \\
\text { Antarctica }\end{array}$ & 2002-2005 AD & $\begin{array}{c}\text { (Kukučka et al., } \\
\text { 2010) }\end{array}$ \\
\hline PAHs & $\begin{array}{l}\text { SPE, elution, } \\
\text { evaporation }\end{array}$ & GC-MS & $10 \mathrm{~L}$ & $82 \pm 8 \%$ & $0.1 \mathrm{ng} / \mathrm{L}$ & $\begin{array}{l}52-272 \mathrm{ng} / \mathrm{L} \\
(\text { ( PAH) }\end{array}$ & $\begin{array}{l}\text { Antarctic snow, } \\
\text { Fildes Peninsula }\end{array}$ & December 2009 & (Na et al., 2011) \\
\hline PAHs & $\begin{array}{c}\text { LLE in GLVE } \\
\text { Solvent Evaporation } \\
\text { Fractionation }\end{array}$ & GC-MS & $15 \mathrm{~L}$ & & $0.01-0.4 \mathrm{ng} / \mathrm{L}$ & $\begin{array}{l}35-660 \mathrm{ng} / \mathrm{L} \\
(\text { (PAH) }\end{array}$ & ice cap, Canada & $\begin{array}{c}8.3 \mathrm{~m} \\
1963-1993 \mathrm{AD}\end{array}$ & $\begin{array}{l}\text { (Peters et al., } \\
\text { 1995) }\end{array}$ \\
\hline PAHs & $\begin{array}{c}\text { On-line SPE on } \\
\text { CFA, elution, } \\
\text { solvent evaporation }\end{array}$ & $\begin{array}{c}\text { HPLC- } \\
\text { fluorescence }\end{array}$ & $250-500 \mathrm{~mL}$ & $71-93 \%$ & $7-466 \mathrm{pg} / \mathrm{L}$ & $0-12 \mathrm{ng} / \mathrm{L}$ & $\begin{array}{c}\text { ice/firn cores, Colle } \\
\text { Gnifetti, Monte } \\
\text { Rosa (Swiss/Italian } \\
\text { Alps) }\end{array}$ & $\begin{array}{c}\sim 58 \mathrm{~m} \\
1700-2003 \mathrm{AD}\end{array}$ & $\begin{array}{l}\text { (Gabrieli et al., } \\
\text { 2010a) }\end{array}$ \\
\hline PAHs & $\begin{array}{c}\text { LLE } \\
\text { Evaporation to } 1 \mathrm{~mL}\end{array}$ & GC-MS & $7 \mathrm{~L}$ & $67-91 \%$ & $2-6 \mathrm{pg} / \mathrm{L}$ & $\begin{array}{c}<4 \mathrm{ng} / \mathrm{L} \\
(\mathrm{PAAH})\end{array}$ & $\begin{array}{c}\text { firn/snow cores, } \\
\text { Talos Dome, } \\
\text { Antarctica }\end{array}$ & $1600-2000 \mathrm{AD}$ & $\begin{array}{l}\text { (Fuoco et al., } \\
\text { 2012) }\end{array}$ \\
\hline
\end{tabular}




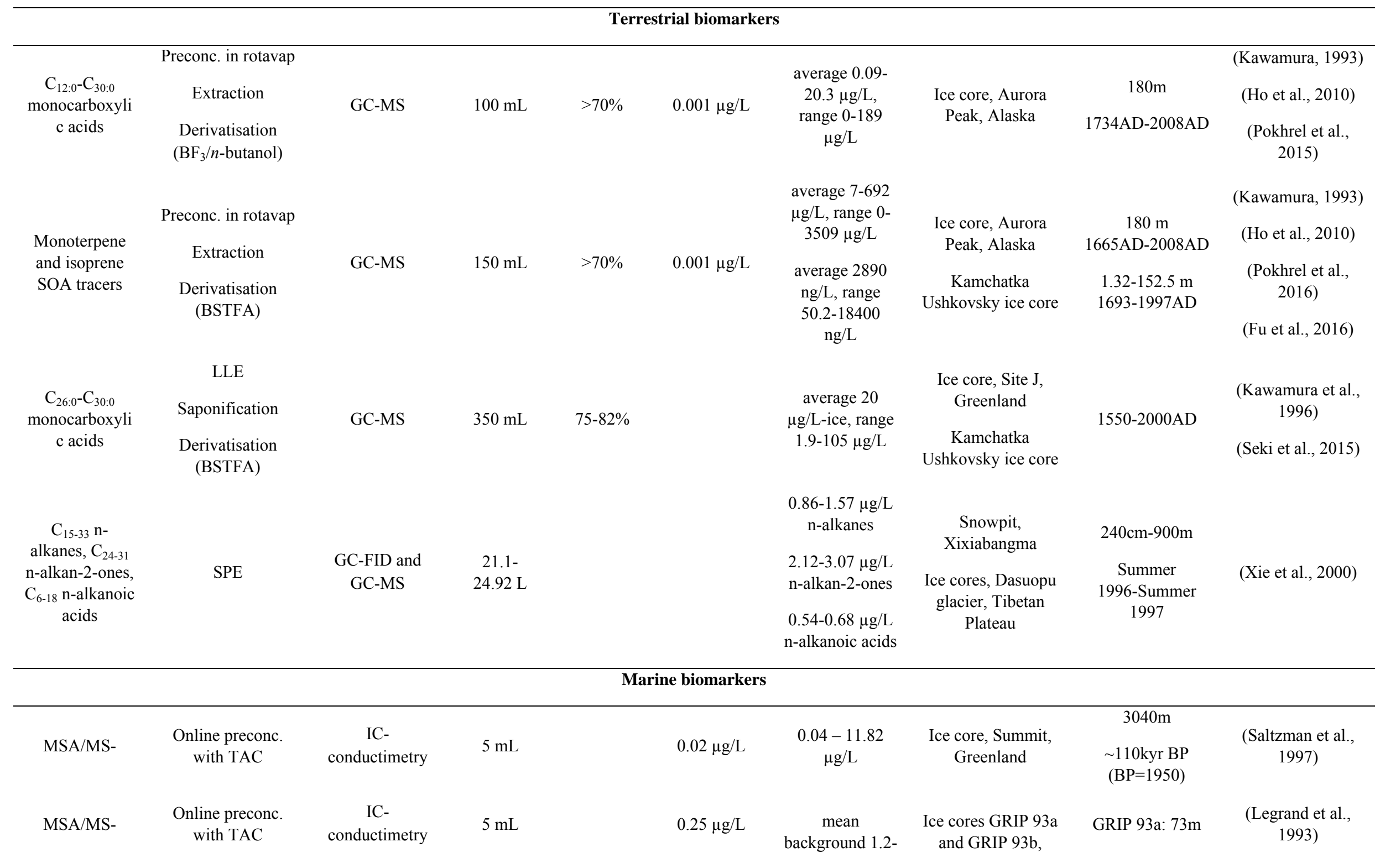




\begin{tabular}{|c|c|c|c|c|c|c|c|c|c|}
\hline & & & & & & $2.9 \mu \mathrm{g} / \mathrm{L}$ & Summit, Greenland & $\begin{array}{l}\text { 1767-1993AD } \\
\text { GRIP 93b 67m, } \\
\text { 1790-1993AD }\end{array}$ & $\begin{array}{l}\text { (Legrand et al., } \\
\text { 1997) }\end{array}$ \\
\hline MSA/MS- & $\begin{array}{l}\text { dil 50:50 with } \\
\text { MeOH } \\
\text { direct injection }\end{array}$ & ESI-MS/MS & $20 \mu \mathrm{L}$ & - & $0.1 \mu \mathrm{g} / \mathrm{L}$ & $\begin{array}{c}\text { range } 1.7-73.2 \\
\mu \mathrm{g} / \mathrm{L}, \operatorname{mean} 14.5 \\
\mu \mathrm{g} / \mathrm{L}\end{array}$ & $\begin{array}{c}\text { Ice core, Siple } \\
\text { Dome, Antarctica }\end{array}$ & $\sim 110 \mathrm{kyr}$ & $\begin{array}{l}\text { (Saltzman et al., } \\
\text { 2006) }\end{array}$ \\
\hline MSA/MS- & direct injection & $\begin{array}{c}\text { IC- } \\
\text { conductimetry }\end{array}$ & $0.8 \mathrm{~mL}$ & - & $0.3 \mu \mathrm{g} / \mathrm{L}$ & $\begin{array}{c}\text { mean } 5.6 \mu \mathrm{g} / \mathrm{L} \\
\text { range } 0-51.1 \\
\mu \mathrm{g} / \mathrm{L}\end{array}$ & $\begin{array}{c}\text { Ice core } \\
\text { Lomonosovfonna, } \\
\text { Svalbard }\end{array}$ & $\begin{array}{c}121 \mathrm{~m} \\
1800-1997 \mathrm{AD}\end{array}$ & $\begin{array}{l}\text { (Jauhiainen et al., } \\
\text { 1999) } \\
\text { (Isaksson et al., } \\
\text { 2005) }\end{array}$ \\
\hline MSA/MS- & $\begin{array}{l}\text { Online preconc. } \\
\text { with TAC }\end{array}$ & $\begin{array}{l}\text { IC- } \\
\text { conductimetry }\end{array}$ & $5 \mathrm{~mL}$ & & $\sim 0.1 \mu \mathrm{g} / \mathrm{L}$ & $\begin{array}{c}\sim 2.88-13.45 \\
\mu \mathrm{g} / \mathrm{L}\end{array}$ & $\begin{array}{l}\text { Ice core, Law } \\
\text { Dome, Antarctica }\end{array}$ & 1841-1995AD & $\begin{array}{l}\text { (Curran and } \\
\text { Palmer, 2001) } \\
\text { (Curran et al., } \\
\text { 2003) }\end{array}$ \\
\hline MSA/MS- & $\begin{array}{l}\text { Online preconc. } \\
\text { with TAC }\end{array}$ & $\begin{array}{l}\text { IC- } \\
\text { conductimetry }\end{array}$ & $3 \mathrm{~mL}$ & & $0.15 \mu \mathrm{g} / \mathrm{L}$ & $\begin{array}{c}\text { mean } 3.30 \mu \mathrm{g} / \mathrm{L}, \\
\text { range } 0.16- \\
38.12 \mu \mathrm{g} / \mathrm{L}\end{array}$ & $\begin{array}{l}\text { Ice core 20D, } \\
\text { Greenland }\end{array}$ & $\begin{array}{c}116 \mathrm{~m} \\
1767-1984 \mathrm{AD}\end{array}$ & $\begin{array}{c}\text { (Whung et al., } \\
\text { 1994) }\end{array}$ \\
\hline $\begin{array}{c}\text { Oleic acid } \\
\quad\left(\mathrm{C}_{18: 1}\right)\end{array}$ & $\begin{array}{l}\text { Preconc. in rotavap } \\
\text { Extraction } \\
\text { Derivatisation } \\
\text { (BF3/n-butanol) }\end{array}$ & GC-MS & $100 \mathrm{~mL}$ & & $0.001 \mu \mathrm{g} / \mathrm{L}$ & $\begin{array}{c}\text { mean } 0.09-20.3 \\
\mu \mathrm{g} / \mathrm{L}, \text { range } 0- \\
189 \mu \mathrm{g} / \mathrm{L}\end{array}$ & $\begin{array}{c}\text { Ice core, Aurora } \\
\text { Peak, Alaska }\end{array}$ & $\begin{array}{c}180 \mathrm{~m} \\
\text { 274y BP (i.e. } \\
1734 \mathrm{AD}- \\
2008 \mathrm{AD})\end{array}$ & $\begin{array}{l}\text { (Pokhrel et al., } \\
\text { 2015) }\end{array}$ \\
\hline $\begin{array}{l}\text { Oleic acid } \\
\qquad\left(C_{18: 1}\right)\end{array}$ & $\begin{array}{c}\text { LLE } \\
\text { Saponification } \\
\text { Derivatisation } \\
\text { (BSTFA) }\end{array}$ & GC-MS & $350 \mathrm{~mL}$ & $75-82 \%$ & & $\begin{array}{c}\text { mean } 20 \mu \mathrm{g} / \mathrm{L}, \\
\text { range } 1.9-105 \\
\mu \mathrm{g} / \mathrm{L}\end{array}$ & Ice core, Greenland & 1550-2000AD & $\begin{array}{c}\text { (Kawamura et al., } \\
\text { 1996) } \\
\text { (Seki et al., 2015) }\end{array}$ \\
\hline $\begin{array}{c}\text { Azelaic acid, } \\
\text { low molecular } \\
\text { weight } \\
\text { dicarboxylic }\end{array}$ & $\begin{array}{l}\text { Preconc. in rotavap } \\
\text { Extraction }\end{array}$ & $\begin{array}{l}\text { GC-FID } \\
\text { GC-MS }\end{array}$ & $150 \mathrm{~mL}$ & $70->90 \%$ & & $\begin{array}{c}\text { Total } \\
\text { dicarboxylic } \\
\text { acids }\left(\mathrm{C}_{2}-\mathrm{C}_{10}\right)\end{array}$ & $\begin{array}{l}\text { Ice core, Site-J, } \\
\text { Greenland }\end{array}$ & $\begin{array}{c}0-205 \mathrm{~m} \\
1546-1989 \mathrm{AD}\end{array}$ & $\begin{array}{c}\text { (Kawamura et al., } \\
\text { 1999) } \\
\text { (Kawamura et al., }\end{array}$ \\
\hline
\end{tabular}




\begin{tabular}{|c|c|c|c|c|c|c|c|c|c|}
\hline acids & $\begin{array}{l}\text { Derivatisation } \\
\text { (BF3/n-butanol) }\end{array}$ & \multicolumn{7}{|c|}{$\begin{array}{c}\text { range } 3.11-32.5 \\
\mu \mathrm{g} / \mathrm{L}\end{array}$} & \multirow[t]{2}{*}{ 2001) } \\
\hline \multicolumn{9}{|c|}{ Biomass burning markers } & \\
\hline Levoglucosan & direct injection & $\begin{array}{c}\text { HPLC-ESI(-)- } \\
\text { MS/MS }\end{array}$ & $100 \mu \mathrm{L}$ & - & $3 \mathrm{ng} / \mathrm{L}$ & $4-30 \mathrm{ng} / \mathrm{L}$ & Dome C, Antarctica & $\begin{array}{c}2396.8 \mathrm{~m}(274.1 \\
\text { kyr BP }) \\
2721.4 \mathrm{~m}(401.6 \\
\text { kyr BP })\end{array}$ & $\begin{array}{c}\text { (Gambaro et al., } \\
\text { 2008) }\end{array}$ \\
\hline Levoglucosan & direct injection & $\begin{array}{c}\text { HPLC-ESI(-)- } \\
\text { MS/MS }\end{array}$ & $100 \mu \mathrm{L}$ & - & $3 \mathrm{ng} / \mathrm{L}$ & $\begin{array}{c}\text { up to } \sim 600 \\
\mu \mathrm{g} / \mathrm{L}\end{array}$ & Summit, Greenland & $3 \mathrm{~m}$ snowpit & $\begin{array}{l}\text { (Gambaro et al., } \\
\text { 2008) } \\
\text { (Kehrwald et al., } \\
\text { 2012) }\end{array}$ \\
\hline Levoglucosan & direct injection & $\begin{array}{c}\text { HPLC-ESI(-)- } \\
\text { MS/MS }\end{array}$ & $100 \mu \mathrm{L}$ & - & $3 \mathrm{ng} / \mathrm{L}$ & $9-1767 \mathrm{ng} / \mathrm{L}$ & NEEM, Greenland & $\begin{array}{l}4.95-602.25 \mathrm{~m} \\
1999 \mathrm{CE}-1036 \\
\text { BCE }\end{array}$ & $\begin{array}{c}\text { (Gambaro et al., } \\
2008) \\
\text { (Zennaro et al., } \\
2014) \\
\text { (Zennaro et al., } \\
2015)\end{array}$ \\
\hline Levoglucosan & direct injection & $\begin{array}{c}\text { HPLC-ESI(+)- } \\
\text { MS/MS }\end{array}$ & $1 \mathrm{~mL}$ & - & $10 \mu \mathrm{g} / \mathrm{L}$ & $\begin{array}{c}10-718 \mu \mathrm{g} / \mathrm{L}, \\
\text { mean } 33 \mu \mathrm{g} / \mathrm{L} \\
\text { (Muztagh Ata) } \\
10-93 \mu \mathrm{g} / \mathrm{L}, \\
\text { mean } 39 \mu \mathrm{g} / \mathrm{L} \\
\text { (Longxiazailong } \\
\text { ba) }\end{array}$ & $\begin{array}{c}\text { Muztagh Ata and } \\
\text { Longxiazailongba } \\
\text { glaciers, Tibetan } \\
\text { Plateau }\end{array}$ & $\begin{array}{c}\text { Muztagh Ata } \\
71 \mathrm{~m} \\
\text { Longxiazailongba } \\
190 \mathrm{~m}\end{array}$ & (Yao et al., 2013) \\
\hline Levoglucosan & $\begin{array}{l}\text { dil. 50:50 with AcN } \\
\text { direct injection }\end{array}$ & $\begin{array}{l}\text { UHPLC-ESI(-)- } \\
\text { MS/MS }\end{array}$ & $\begin{array}{c}5 \mu \mathrm{L}(\mathrm{dil} \\
50: 50)\end{array}$ & - & $0.11 \mu \mathrm{g} / \mathrm{L}$ & $\begin{array}{c}\text { mean } 0.28-1.14 \\
\mu \mathrm{g} / \mathrm{L} \text { (snow) } \\
\text { LOD-7.56 } \mu \mathrm{g} / \mathrm{L} \\
\quad \text { (ice core) }\end{array}$ & $\begin{array}{c}\text { Snow and ice core } \\
\text { Zangsegangri, } \\
\text { Tibetan Plateau }\end{array}$ & & (You et al., 2016) \\
\hline $\begin{array}{l}\text { Levoglucosan, } \\
\text { mannosan, }\end{array}$ & Freeze-drying & GC/MS & $5 \mathrm{~mL}$ & $65-81 \%$ & $\begin{array}{c}0.070 \mu \mathrm{g} / \mathrm{L} \\
\text { (levoglucosan }\end{array}$ & up to $1.93 \mu \mathrm{g} / \mathrm{L}$ & $\begin{array}{c}\text { Muztagh Ata and } \\
\text { Kuokuosele }\end{array}$ & & (You et al., 2014) \\
\hline
\end{tabular}




\section{galactosan \\ Extraction \\ Derivatization \\ (MSTFA)}

Preconc. in rotavap

Levoglucosan,

mannosan,

galactosan

Vanillic acid

Extraction

Derivatization (BSTFA)

dil. 50:50 with

$\mathrm{MeOH}$

\section{CFA}

Preconc. in rotavap

Vanillic acid

$$
\begin{gathered}
\text { Extraction } \\
\text { Derivatization } \\
\text { (BSTFA) }
\end{gathered}
$$

$$
\text { Vanillic acid }
$$$$
\text { direct injection }
$$

Methyl dehydroabietate

filtration, essication

Preconc. in rotavap

$\begin{array}{cc}\begin{array}{c}\text { Dehydroabietic } \\ \text { acid }\end{array} & \text { Extraction } \\ & \text { Derivatization } \\ & \text { (BSTFA) }\end{array}$

p- Preconc. in rotavap

$$
\begin{gathered}
\text { ) } \\
0.058 \mu \mathrm{g} / \mathrm{L} \\
\text { (mannosan) } \\
\\
0.046 \mu \mathrm{g} / \mathrm{L} \\
\text { (galactosan) }
\end{gathered}
$$

$$
\text { CG/MS } \quad 80-250 \mathrm{~mL} \quad 73 \pm 10 \% \quad 0.005 \mu \mathrm{g} / \mathrm{L}
$$

$73 \pm 10 \%$

up to $19 \mu \mathrm{g} / \mathrm{L}$

Ushkovsky ice cap,
Kamchatka

D4, Greenland

ESI(-)-MS/MS

$7.6-368.2 \mathrm{ng} / \mathrm{L}$

up to $0.13 \mu \mathrm{g} / \mathrm{L}$

SFE-GC/MS ${ }^{\mathrm{e}} \quad 100-200 \mathrm{~mL}$

CG/MS

$80-250 \mathrm{~mL}$

$67 \pm 40 \%$

$0.003 \mu \mathrm{g} / \mathrm{L}$

CG/MS

$80-250 \mathrm{~mL} \quad 78 \pm 18 \% \quad 0.005 \mu \mathrm{g} / \mathrm{L}$ mean 0.015

$\mu \mathrm{g} / \mathrm{L}$

$$
\begin{gathered}
59-698 \mathrm{ng} / \mathrm{L} \\
\text { mean } 226 \pm 189 \\
\mathrm{ng} / \mathrm{L}
\end{gathered}
$$

Ushkovsky ice cap,

Kamchatka

$1.32-152.6 \mathrm{~m}$

$1997-1963$ AD

Kawamura et al.,

$$
\text { 2012) }
$$

Akademii Nauk,

$200-350 \mathrm{AD}$

(Grieman et al., 2015)

GISP2, Greenland

3 m snowpit 1994-1995 AD

(Slater et al., 2002)

up to $0.47 \mu \mathrm{g} / \mathrm{L}$

mean 0.054

$\mu \mathrm{g} / \mathrm{L}$

Ushkovsky ice cap,

$1.32-152.6 \mathrm{~m}$

1997 - 1963 AD

(Kawamura et al., 2012)

up to $1.74 \mu \mathrm{g} / \mathrm{L}$ 
acid Extraction

mean $0.24 \mu \mathrm{g} / \mathrm{L}$

Derivatization

(BSTFA)

\begin{tabular}{|c|c|c|c|c|c|c|c|c|c|}
\hline Oxalate & $\begin{array}{c}\text { Preconc. in rotavap } \\
\text { Extraction } \\
\text { Derivatisation } \\
\text { (BF3/n-butanol) }\end{array}$ & $\begin{array}{l}\text { GC-FID } \\
\text { GC-MS }\end{array}$ & $150 \mathrm{~mL}$ & $70->90 \%$ & & $\begin{array}{c}\text { mean } 2.10 \mu \mathrm{g} / \mathrm{L} \\
\text { range } 0.36-10.7 \\
\mu \mathrm{g} / \mathrm{L}\end{array}$ & $\begin{array}{l}\text { Ice core, Site-J, } \\
\text { Greenland }\end{array}$ & $\begin{array}{c}0-205 \mathrm{~m} \\
1546-1989 A D\end{array}$ & $\begin{array}{l}\text { (Kawamura et al., } \\
\text { 1999) } \\
\text { (Kawamura et al., } \\
\text { 2001) }\end{array}$ \\
\hline Oxalate & & $\begin{array}{c}\text { IC- } \\
\text { conductimetry }\end{array}$ & & & $0.5 \mu \mathrm{g} / \mathrm{L}$ & $\begin{array}{l}\text { background 0.1- } \\
\quad 0.8 \mu \mathrm{g} / \mathrm{L} \\
\text { mean } 0.4 \mu \mathrm{g} / \mathrm{L} \\
\text { non-bb } 0.3 \mu \mathrm{g} / \mathrm{L}\end{array}$ & Summit, Greenland & 1767-1993 AD & $\begin{array}{c}\text { (Legrand et al., } \\
\text { 1993) } \\
\text { (Legrand and De } \\
\text { Angelis, 1996) }\end{array}$ \\
\hline Oxalate & & $\begin{array}{c}\text { IC- } \\
\text { conductimetry }\end{array}$ & & & & $0.1-9.5 \mu \mathrm{g} / \mathrm{L}$ & Summit, Greenland & $3 \mathrm{~m}$ snowpit & $\begin{array}{c}\text { (Kehrwald et al., } \\
\text { 2012) }\end{array}$ \\
\hline
\end{tabular}

${ }^{a}$ LODs refer to concentration in initial sample (i.e. melted ice or snow). ${ }^{b}$ Arctic and Antarctic ice cores samples were considered whenever available. When not available, literature search has been extended to fresh snow and ice-cores from mountain glaciers. ${ }^{c}$ References refer to measurements of snow and ice samples, and description of analytical methods and their performances. ${ }^{\mathrm{d}}$ GLVE $=$ Goulden large-volume extractor. ${ }^{\mathrm{e}} \mathrm{SFE}=$ Supercritical Fluid Extraction 
Table 2. Isoprene, Monoterpene and Sesquiterpene SOA compounds identified in natural atmospheric aerosol samples from forest locations and in snow samples from remote locations.

\begin{tabular}{|c|c|}
\hline Isoprene SOA & Location \\
\hline $\begin{array}{l}\text { 2-methyltetrols: } \\
\text { 2-methylthreitol } \\
\text { 2-methylerythritol }\end{array}$ & $\begin{array}{l}\text { Canadian High Arctic (Fu et al., 2009), Boreal Forest Finland } \\
\text { (Kourtchev et al., 2013; Kourtchev et al., 2005), Forested areas } \\
\text { China (Wang et al., 2008), Amazonian Forest Brazil (Claeys et al., } \\
\text { 2004a), Tibetan Plateau (Shen et al., 2015), Alaskan ice core } \\
\text { (Pokhrel et al., 2016), Kamchatka ice core (Fu et al., 2016) }\end{array}$ \\
\hline 2-methylglyceric acid & $\begin{array}{l}\text { Canadian High Arctic (Fu et al., 2009), Boreal Forest Finland } \\
\text { (Kourtchev et al., 2013; Kourtchev et al., 2005), Forested areas } \\
\text { China (Wang et al., 2008), Tibetan Plateau (Shen et al., 2015), } \\
\text { Alaskan ice core (Pokhrel et al., 2016), Kamchatka ice core (Fu et } \\
\text { al., 2016) }\end{array}$ \\
\hline $\begin{array}{l}\mathrm{C}_{5} \text {-alkene triols: } \\
\text { cis-2-methyl-1,3,4,trihydroxy-1- } \\
\text { butene } \\
\text { trans-2-methyl-1,3,4-trihydroxy-1- } \\
\text { butene } \\
\text { 3-methyl-2,3,4-trihydroxy-1-butene }\end{array}$ & $\begin{array}{l}\text { Canadian High Arctic (Fu et al., 2009), Boreal Forest Finland } \\
\text { (Kourtchev et al., 2005), Forested areas China (Wang et al., 2008), } \\
\text { Tibetan Plateau (Shen et al., 2015), Alaskan ice core (Pokhrel et al., } \\
\text { 2016) }\end{array}$ \\
\hline Monoterpene SOA & Location \\
\hline
\end{tabular}

3-hydroxyglutaric acid

Canadian High Arctic (Fu et al., 2009), Forested areas China (Wang et al., 2008), Alaskan ice core (Pokhrel et al., 2016), Kamchatka ice core (Fu et al., 2016)

pinic acid, pinonic acid Canadian High Arctic (Fu et al., 2009), Boreal Forest Finland (Kourtchev et al., 2013), Tibetan Plateau (Shen et al., 2015), Alaskan ice core (Pokhrel et al., 2016), Kamchatka ice core (Fu et al., 2016)

pinanoldehyde; pinanediol mononitrate; Boreal Forest Finland (Kourtchev et al., 2013) norpinonic acid; terebic acid; ketolimononic acid; limonic acid; homoterpenylic acid; deterpenylic acid acetate; caric acid; caronic acid; 2-hydroxyterpenylic acid; HHDCA (1-hydroxy-3-(hydroxymethyl)- 2,2 dimethylcyclobutane-carboxylic acid); DHHMDMCP (2,3-dihydroxy2-(hydroxymethyl)-7,7dimethylbicycloheptan6-one); HODSA (3-(2-hydroxy-3-oxobutyl)2,2-dimethylsuccinaldehyde); 2,6,6trimethylbicycloheptane-2,3,-diol norpinic acid

3-hydroxyglutaric acid, 3-hydroxy-4,4dimethylglutaric acid

MBTCA (3-methyl-1,2,3butanetricarboxylic acid)

Canadian High Arctic (Fu et al., 2009), Boreal Forest Finland (Kourtchev et al., 2013), Forested areas China (Wang et al., 2008) Tibetan Plateau (Shen et al., 2015)

Canadian High Arctic (Fu et al., 2009), Boreal Forest Finland (Kourtchev et al., 2013), Forested areas China (Wang et al., 2008), Tibetan Plateau (Shen et al., 2015), Kamchatka ice core (Fu et al., 2016)

\begin{tabular}{ll}
\hline Sesquiterpene SOA & Location \\
\hline$\beta$-caryophyllinic acid & Canadian High Arctic (Fu et al., 2009), North Carolina, USA (Jaoui \\
& et al., 2007), Boreal Forest Finland (van Eijck et al., 2013), Tibetan \\
& Plateau (Shen et al., 2015)
\end{tabular}


DCCA (3,3-dimethyl-2-

(3oxobutyl)cyclobutanecarboxylic

acid)

$\beta$-nocaryophyllonic acid; 2-(2carboxyethyl)-3,3-

dimethylcyclobutanecarboxylic acid
Boreal Forest Finland (Kourtchev et al., 2013; van Eijck et al., 2013)

Boreal Forest Finland (van Eijck et al., 2013)

1026 
Table 3. The "Dirty Dozen" of Persistent Organic Pollutants (POPs) as identified by the Stockholm Convention determined in polar regions.

\begin{tabular}{|c|c|c|}
\hline POP & Global Historical Use/Source & Presence in polar regions \\
\hline Aldrin and Dieldrin & Insecticide; Also used for termite control. & $\begin{array}{l}\text { Austfonna, Svalbard, ice core } \\
\text { (Hermanson et al., 2005); Seawater } \\
\text { and pack ice, Terra Nova Bay, } \\
\text { Antarctica (Desideri et al., 1991) }\end{array}$ \\
\hline Chlordane & $\begin{array}{l}\text { Insecticide; Used on home lawn and garden } \\
\text { pests. Also used extensively to control } \\
\text { termites. }\end{array}$ & $\begin{array}{l}\text { Holtedahlfonna, Svalbard ice core } \\
\text { (Ruggirello et al., 2010); Alaskan } \\
\text { sea ice (Garbarino et al., 2002) }\end{array}$ \\
\hline DDT & $\begin{array}{l}\text { Insecticide for insects that carry diseases such } \\
\text { as malaria and typhus. }\end{array}$ & $\begin{array}{l}\text { Antarctic glacier ice as inferred } \\
\text { from Adelie penguin DDT } \\
\text { concentrations (Geisz et al., 2008) }\end{array}$ \\
\hline Endrin & Insecticide; Also used to control rodents. & $\begin{array}{l}\text { Holtedahlfonna, Svalbard ice core } \\
\text { (Ruggirello et al., 2010) }\end{array}$ \\
\hline Mirex & $\begin{array}{l}\text { Insecticide; Also used as a fire retardant in } \\
\text { plastics, rubber, and electrical products. }\end{array}$ & $\begin{array}{l}\text { Arctic foxes (Andersen et al., } \\
\text { 2015) }\end{array}$ \\
\hline Heptachlor & $\begin{array}{l}\text { Insecticide used primarily against soil insects } \\
\text { and termites. Also used against some crop } \\
\text { pests and to combat malaria. }\end{array}$ & $\begin{array}{l}\text { Atmospheric samples from north- } \\
\text { east Greenland (Bossi et al., 2013); } \\
\text { Air, seawater, sea ice, and snow in } \\
\text { the western Antarctic Peninsula } \\
\text { (Dickhut et al., 2005) }\end{array}$ \\
\hline Hexachlorobenzene & $\begin{array}{l}\text { Fungicide used for seed treatment. Also an } \\
\text { industrial chemical used to make fireworks, } \\
\text { ammunition, synthetic rubber, and other } \\
\text { substances. Also unintentionally produced } \\
\text { during combustion. }\end{array}$ & $\begin{array}{l}\text { Arctic Ocean sea water and } \\
\text { boundary layer air (Cai et al., } \\
\text { 2012); North-east Greenland air } \\
\text { (Bossi et al., 2013); Antarctic } \\
\text { peninsula snow (Dickhut et al., } \\
\text { 2005) }\end{array}$ \\
\hline PCBs & $\begin{array}{l}\text { Used for a variety of industrial processes and } \\
\text { purposes, including in electrical transformers } \\
\text { and capacitors, as heat exchange fluids, as } \\
\text { paint additives, in carbonless copy paper, and } \\
\text { in plastics. Also unintentionally produced } \\
\text { during combustion. }\end{array}$ & $\begin{array}{l}\text { Talos Dome, Antarctica snow/ice } \\
\text { cores (Fuoco et al., 2012); } \\
\text { Northern Victoria Land, Antarctica } \\
\text { surface snow (Vecchiato et al., } \\
\text { 2015) }\end{array}$ \\
\hline Toxaphene & $\begin{array}{l}\text { Insecticide; also used and to kill unwanted fish } \\
\text { in lakes. }\end{array}$ & $\begin{array}{l}\text { Arctic Ocean seawater (Macdonald } \\
\text { et al., } 2000 \text { and references therein) }\end{array}$ \\
\hline Dioxins and Furans & $\begin{array}{l}\text { Unintentionally produced during most forms of } \\
\text { combustion, including burning of municipal } \\
\text { and medical wastes }\end{array}$ & $\begin{array}{l}\text { Canadian Arctic ringed seals and } \\
\text { polar bears (Muir et al., 1992) }\end{array}$ \\
\hline \multicolumn{3}{|c|}{$\begin{array}{l}\text { The "POPs" and "Global Historical Use/Source" columns are modified from the U.S. Environmental Protection } \\
\text { Agency (US EPA): } \\
\text { https://www.epa.gov/international-cooperation/persistent-organic-pollutants-global-issue-global-response } \\
\text { The compiled literature gives precedence first to polar snow and ice studies, then seawater and atmospheric } \\
\text { studies, and if such research was not available, then biological studies are included in the summary. }\end{array}$} \\
\hline
\end{tabular}


1032 Aarhus-Protocol, 1998. Protocol to the 1979 Convention on Long-Range Transboundary Air Pollution on Persistent Organic Pollutants; United Nations Economic Commission for 1034 Europe: Geneva.

1035 Abram, N.J., Curran, M.A.J., Mulvaney, R., Vance, T., 2008. The preservation of methanesulphonic acid in frozen ice-core samples. J Glaciol 54, 680-684.

1037 Abram, N.J., Mulvaney, R., Wolff, E.W., Mudelsee, M., 2007. Ice core records as sea ice proxies: An evaluation from the Weddell Sea region of Antarctica. J. Geophys. Res.-Atmos. 112.

1040 Abram, N.J., Thomas, E.R., McConnell, J.R., Mulvaney, R., Bracegirdle, T.J., Sime, L.C., 1041 Aristarain, A.J., 2010. Ice core evidence for a 20th century decline of sea ice in the 1042 Bellingshausen Sea, Antarctica. J. Geophys. Res.-Atmos. 115.

1043 Ahrens, L., Shoeib, M., Del Vento, S., Codling, G., Halsall, C., 2011. Polyfluoroalkyl 1044 compounds in the Canadian Arctic atmosphere. Environ Chem 8, 399-406.

1045 Andersen, M.S., Fuglei, E., Konig, M., Lipasti, I., Pedersen, A.O., Polder, A., Yoccoz, N.G., 1046 Routti, H., 2015. Levels and temporal trends of persistent organic pollutants (POPs) in arctic foxes (Vulpes lagopus) from Svalbard in relation to dietary habits and food availability. Sci Total Environ 511, 112-122.

Anderson, P.N., Hites, R.A., 1996. OH Radical Reactions: The Major Removal Pathway for Polychlorinated Biphenyls from the Atmosphere. Environmental Science \& Technology 30, 1756-1763.

Armitage, J.M., MacLeod, M., Cousins, I.T., 2009. Modeling the Global Fate and Transport of Perfluorooctanoic Acid (PFOA) and Perfluorooctanoate (PFO) Emitted from Direct Sources Using a Multispecies Mass Balance Model. Environmental Science \& Technology $43,1134-1140$. environment as revealed by analysis of ice and snow. Earth-Science Reviews 168, 218-231.

Barrie, L.A., Gregor, D., Hargrave, B., Lake, R., Muir, D., Shearer, R., Tracey, B., Bidleman, T., 1992. Arctic contaminants: sources, occurrence and pathways. Sci Total Environ 122, 174.

Barron, M.G., Holder, E., 2003. Are Exposure and Ecological Risks of PAHs Underestimated at Petroleum Contaminated Sites? Human and Ecological Risk Assessment: An International Journal 9, 1533-1545.

1064 Becagli, S., Castellano, E., Cerri, O., Curran, M., Frezzotti, M., Marino, F., Morganti, A., 1065 Proposito, M., Severi, M., Traversi, R., Udisti, R., 2009. Methanesulphonic acid (MSA) 1066 stratigraphy from a Talos Dome ice core as a tool in depicting sea ice changes and southern 1067 atmospheric circulation over the previous 140 years. Atmospheric Environment 43, 105110681058. 
Bedini, E., 2011. Mineral mapping in the Kap Simpson complex, central East Greenland, using HyMap and ASTER remote sensing data. Advances in Space Research 47, 60-73.

1071 Bendle, J., Kawamura, K., Yamazaki, K., Niwai, T., 2007. Latitudinal distribution of terrestrial lipid biomarkers and n-alkane compound-specific stable carbon isotope ratios in the atmosphere over the western Pacific and Southern Ocean. Geochim Cosmochim Ac 71, 5934-5955.

Benskin, J.P., Ahrens, L., Muir, D.C., Scott, B.F., Spencer, C., Rosenberg, B., Tomy, G., Kylin, H., Lohmann, R., Martin, J.W., 2012. Manufacturing origin of perfluorooctanoate (PFOA) in Atlantic and Canadian Arctic seawater. Environ Sci Technol 46, 677-685.

Blais, J.M., Schindler, D.W., Derek, C.G.M., Sharp, M., Donald, D., Lafreni, xe, re, M., 415.

Bonmatin, J.-M., Giorio, C., Girolami, V., Goulson, D., Kreutzweiser, D.P., Krupke, C., Liess, M., Long, E., Marzaro, M., Mitchell, E.A., Noome, D.A., Simon-Delso, N., Tapparo, A., 2015. Environmental fate and exposure; neonicotinoids and fipronil. Environmental Science and Pollution Research 22, 35-67.

1086 Bonsang, B., Polle, C., Lambert, G., 1992. Evidence for marine production of isoprene. 1087 Geophysical Research Letters 19, 1129-1132.

1088 Bory, A., Wolff, E., Mulvaney, R., Jagoutz, E., Wegner, A., Ruth, U., Elderfield, H., 2010. 1089 Multiple sources supply eolian mineral dust to the Atlantic sector of coastal Antarctica:

1090 Evidence from recent snow layers at the top of Berkner Island ice sheet. Earth Planet. Sci.

1091 Lett. 291, 138-148.

1092 Bosle, J.M., Mischel, S.A., Schulze, A.-L., Scholz, D., Hoffmann, T., 2014. Quantification of 1093 low molecular weight fatty acids in cave drip water and speleothems using HPLC-ESI-IT/MS 1094 - development and validation of a selective method. Anal Bioanal Chem 406, 3167-3177. atmospheric concentrations of organochlorine pesticides (OCPs) at Station Nord, North-East Greenland. Environ Sci Process Impacts 15, 2213-2219.

1101 Brönnimann, S., Voigt, S., Wanner, H., 2000. The influence of changing UVB radiation in near-surface ozone time series. Journal of Geophysical Research: Atmospheres 105, 89018913.

1104 Buck, R.C., Franklin, J., Berger, U., Conder, J.M., Cousins, I.T., de Voogt, P., Jensen, A.A., 
1108 Cai, M., Ma, Y., Xie, Z., Zhong, G., Möller, A., Yang, H., Sturm, R., He, J., Ebinghaus, R., 1109 Meng, X.-Z., 2012. Distribution and air-sea exchange of organochlorine pesticides in the 1110 North Pacific and the Arctic. Journal of Geophysical Research: Atmospheres 117, n/a-n/a.

1111 Candelone, J.-P., Hong, S., F. Boutron, C., 1994. An improved method for decontaminating 1112 polar snow or ice cores for heavy metal analysis. Anal Chim Acta 299, 9-16.

1113 Carlton, A.G., Wiedinmyer, C., Kroll, J.H., 2009. A review of Secondary Organic Aerosol 1114 (SOA) formation from isoprene. Atmos Chem Phys 9, 4987-5005.

1115 Chen, D., Hale, R.C., La Guardia, M.J., Luellen, D., Kim, S., Geisz, H.N., 2015.

1116 Hexabromocyclododecane flame retardant in Antarctica: Research stations as sources.

1117 Environ Pollut 206, 611-618.

1118 Claeys, M., Graham, B., Vas, G., Wang, W., Vermeylen, R., Pashynska, V., Cafmeyer, J., 1119 Guyon, P., Andreae, M.O., Artaxo, P., Maenhaut, W., 2004a. Formation of secondary organic 1120 aerosols through photooxidation of isoprene. Science 303, 1173-1176.

1121 Claeys, M., Wang, W., Ion, A.C., Kourtchev, I., Gelencsér, A., Maenhaut, W., 2004b.

1122 Formation of secondary organic aerosols from isoprene and its gas-phase oxidation products 1123 through reaction with hydrogen peroxide. Atmospheric Environment 38, 4093-4098.

1124 Claeys, M., Wang, W., Vermeylen, R., Kourtchev, I., Chi, X., Farhat, Y., Surratt, J.D., 1125 Gómez-González, Y., Sciare, J., Maenhaut, W., 2010. Chemical characterisation of marine 1126 aerosol at Amsterdam Island during the austral summer of 2006-2007. Journal of Aerosol 1127 Science 41, 13-22.

1128 Conedera, M., Tinner, W., Neff, C., Meurer, M., Dickens, A.F., Krebs, P., 2009.

1129 Reconstructing past fire regimes: methods, applications, and relevance to fire management 1130 and conservation. Quat. Sci. Rev. 28, 555-576.

1131 Criscitiello, A.S., Das, S.B., Evans, M.J., Frey, K.E., Conway, H., Joughin, I., Medley, B., 1132 Steig, E.J., 2013. Ice sheet record of recent sea-ice behavior and polynya variability in the 1133 Amundsen Sea, West Antarctica. Journal of Geophysical Research: Oceans 118, 118-130.

1134 Curran, M.A.J., Jones, G.B., 2000. Dimethyl sulfide in the Southern Ocean: Seasonality and 1135 flux. Journal of Geophysical Research: Atmospheres 105, 20451-20459.

1136 Curran, M.A.J., Palmer, A.S., 2001. Suppressed ion chromatography methods for the routine 1137 determination of ultra low level anions and cations in ice cores. J Chromatogr A 919, 1071138113.

1139 Curran, M.A.J., van Ommen, T.D., Morgan, V.I., Phillips, K.L., Palmer, A.S., 2003. Ice core 1140 evidence for Antarctic sea ice decline since the 1950s. Science 302, 1203-1206.

1141 Currie, L.A., Dibb, J.E., Klouda, G.A., Benner, B.A., Conny, J.M., Biegalski, S.R., 1142 Klinedinst, D.B., Cahoon, D.R., Hsu, N.C., 1998. The pursuit of isotopic and molecular fire 1143 tracers in the polar atmosphere and cryosphere. Radiocarbon 40, 381-390.

1144 Damoah, R., Spichtinger, N., Forster, C., James, P., Mattis, I., Wandinger, U., Beirle, S., 1145 Wagner, T., Stohl, A., 2004. Around the world in 17 days - hemispheric-scale transport of 1146 forest fire smoke from Russia in May 2003. Atmos Chem Phys 4, 1311-1321. 
1147 De Angelis, M., Traversi, R., Udisti, R., 2012. Long-term trends of mono-carboxylic acids in 1148 Antarctica: Comparison of changes in sources and transport processes at the two EPICA deep 1149 drilling sites. Tellus, Series B: Chemical and Physical Meteorology 64, 1-21.

1150 Delmonte, B., Andersson, P.S., Hansson, M., Schoberg, H., Petit, J.R., Basile-Doelsch, I., 1151 Maggi, V., 2008. Aeolian dust in East Antarctica (EPICA-Dome C and Vostok): Provenance during glacial ages over the last 800 kyr. Geophysical Research Letters 35.

1153 Dentener, F., Kinne, S., Bond, T., Boucher, O., Cofala, J., Generoso, S., Ginoux, P., Gong, 1154 S., Hoelzemann, J.J., Ito, A., Marelli, L., Penner, J.E., Putaud, J.P., Textor, C., Schulz, M., van der Werf, G.R., Wilson, J., 2006. Emissions of primary aerosol and precursor gases in the years 2000 and 1750 prescribed data-sets for AeroCom. Atmos Chem Phys 6, 4321-4344.

1157 Desideri, P., Lepri, L., Santianni, D., Checchini, L., 1991. Chlorinated pesticides in sea-water and pack ice in Terra-Nova Bay (Antarctica). Annali di Chimica 81, 533-540.

1159 Dickhut, R.M., Cincinelli, A., Cochran, M., Ducklow, H.W., 2005. Atmospheric 1160 Concentrations and Air-Water Flux of Organochlorine Pesticides along the Western 1161 Antarctic Peninsula. Environmental Science \& Technology 39, 465-470.

1162 Domine, F., Cincinelli, A., Bonnaud, E., Martellini, T., Picaud, S., 2007. Adsorption of 1163 phenanthrene on natural snow. Environ. Sci. Technol. 41, 6033-6038.

1164 https://doi.org/10.1021/es0706798

1165 Engling, G., Carrico, C.M., Kreldenweis, S.M., Collett, J.L., Day, D.E., Malm, W.C., 1166 Lincoln, E., Hao, W.M., Iinuma, Y., Herrmann, H., 2006. Determination of levoglucosan in biomass combustion aerosol by high-performance anion-exchange chromatography with pulsed amperometric detection. Atmospheric Environment 40, S299-S311.

1169 Epica community members, 2004. Eight glacial cycles from an Antarctic ice core. Nature $1170 \quad 429,623-628$.

1171 Fabbri, D., Torri, C., Simonei, B.R.T., Marynowski, L., Rushdi, A.I., Fabianska, M.J., 2009. 1172 Levoglucosan and other cellulose and lignin markers in emissions from burning of Miocene 1173 lignites. Atmospheric Environment 43, 2286-2295.

1174 Facchini, M.C., Decesari, S., Rinaldi, M., Carbone, C., Finessi, E., Mircea, M., Fuzzi, S., 1175 Moretti, F., Tagliavini, E., Ceburnis, D., O’Dowd, C.D., 2008. Important Source of Marine 1176 Secondary Organic Aerosol from Biogenic Amines. Environmental Science \& Technology 1177 42, 9116-9121.

1178 Ferretti, D.F., Miller, J.B., White, J.W.C., Etheridge, D.M., Lassey, K.R., Lowe, D.C., 1179 Meure, C.M.M., Dreier, M.F., Trudinger, C.M., van Ommen, T.D., Langenfelds, R.L., 2005. 1180 Unexpected changes to the global methane budget over the past 2000 years. Science 309, $1181 \quad 1714-1717$.

1182 Fischer, H., Schüpbach, S., Gfeller, G., Bigler, M., Röthlisberger, R., Erhardt, T., Stocker, 1183 T.F., Mulvaney, R., Wolff, E.W., 2015. Millennial changes in North American wildfire and 1184 soil activity over the last glacial cycle. Nat Geosci 8, 723-728. 
1185 Fischer, H., Siggaard-Andersen, M.-L., Ruth, U., Röthlisberger, R., Wolff, E., 2007.

1186 Glacial/interglacial changes in mineral dust and sea-salt records in polar ice cores: Sources,

1187 transport, and deposition. Rev Geophys 45.

1188 Foster, A.F.M., Curran, M.A.J., Smith, B.T., van Ommen, T.D., Morgan, V.I., 2006.

1189 Covariation of sea ice and methanesulphonic acid in Wilhelm II Land, East Antarctica.

1190 Annals of Glaciology 44, 429-432.

1191 Fraser, M.P., Lakshmanan, K., 2000. Using levoglucosan as a molecular marker for the long1192 range transport of biomass combustion aerosols. Environmental Science \& Technology 34, 1193 4560-4564.

1194 Fu, P.Q., Kawamura, K., Chen, J., Barrie, L.A., 2009. Isoprene, Monoterpene, and 1195 Sesquiterpene Oxidation Products in the High Arctic Aerosols during Late Winter to Early 1196 Summer. Environmental Science \& Technology 43, 4022-4028.

1197 Fu, P.Q., Kawamura, K., Chen, J., Charrière, B., Sempéré, R., 2013. Organic molecular 1198 composition of marine aerosols over the Arctic Ocean in summer: Contributions of primary

1200 Fu, P., Kawamura, K., Seki, O., Izawa, Y., Shiraiwa, T., Ashworth, K., 2016. Historical 1201 Trends of Biogenic SOA Tracers in an Ice Core from Kamchatka Peninsula. Environ. Sci.

1202 Technol. Lett. 3, 351-358. https://doi.org/10.1021/acs.estlett.6b00275

1203 Fundel, F., Fischer, H., Weller, R., Traufetter, F., Oerter, H., Miller, H., 2006. Influence of 1204 large-scale teleconnection patterns on methane sulfonate ice core records in Dronning Maud 1205 Land. Journal of Geophysical Research 111.

1206 Fuoco, R., Giannarelli, S., Onor, M., Ghimenti, S., Abete, C., Termine, M., Francesconi, S., 1207 2012. A snow/firn four-century record of polycyclic aromatic hydrocarbons (PAHs) and 1208 polychlorobiphenyls (PCBs) at Talos Dome (Antarctica). Microchem J 105, 133-141.

1209 Fuoco, R., Giannarelli, S., Wei, Y., Abete, C., Francesconi, S., Termine, M., 2005.

1210 Polychlorobiphenyls and polycyclic aromatic hydrocarbons in the sea-surface micro-layer 1211 and the water column at Gerlache Inlet, Antarctica. J. Environ. Monit. 7, 1313.

1212 https://doi.org/10.1039/b507329b

1213 Gabrieli, J., Decet, F., Luchetta, A., Valt, M., Pastore, P., Barbante, C., 2010a. Occurrence of 1214 PAH in the seasonal snowpack of the Eastern Italian Alps. Environ Pollut 158, 3130-3137.

1215 Gabrieli, J., Vallelonga, P., Cozzi, G., Gabrielli, P., Gambaro, A., Sigl, M., Decet, F.,

1216 Schwikowski, M., Gäggeler, H., Boutron, C., Cescon, P., Barbante, C., 2010b. Post 17th1217 century changes of European PAH emissions recorded in high-altitude Alpine snow and ice.

1218 Environmental science \& technology 44, 3260-3266.

1219 Gambaro, A., Zangrando, R., Gabrielli, P., Barbante, C., Cescon, P., 2008. Direct 1220 determination of levoglucosan at the picogram per milliliter level in Antarctic ice by highperformance liquid chromatography/electrospray ionization triple quadrupole mass spectrometry. Analytical chemistry 80, 1649-1655. 
1223 Garbarino, J.R., Snyder-Conn, E., Leiker, T.J., Hoffman, G.L., 2002. Contaminants in arctic snow collected over northwest Alaskan sea ice. Water, Air, and Soil Pollution 139, 183-214.

1225 Garmash, O., Hermanson, M.H., Isaksson, E., Schwikowski, M., Divine, D., Teixeira, C., Muir, D.C.G., 2013. Deposition History of Polychlorinated Biphenyls to the Lomonosovfonna Glacier, Svalbard: A 209 Congener Analysis. Environmental Science \& Technology 47, 12064-12072.

Geissen, V., Mol, H., Klumpp, E., Umlauf, G., Nadal, M., van der Ploeg, M., van de Zee, S.E.A.T.M., Ritsema, C.J., 2015. Emerging pollutants in the environment: A challenge for water resource management. International Soil and Water Conservation Research 3, 57-65.

Geisz, H.N., Dickhut, R.M., Cochran, M.A., Fraser, W.R., Ducklow, H.W., 2008. Melting glaciers: A probable source of DDT to the Antarctic marine ecosystem. Environmental Science and Technology 42, 3958-3962.

Giannarelli, S., Ceccarini, A., Tiribilli, C., Spreafico, R., Francesconi, S., Fuoco, R., 2017. Paleo-environmental record of polycyclic aromatic hydrocarbons and polychlorobiphenyls at the peripheral site GV7 in Victoria Land (East Antarctica). Chemosphere 174, 390-398. https://doi.org/10.1016/j.chemosphere.2017.01.126

Giorio, C., Safer, A., Sánchez-Bayo, F., Tapparo, A., Lentola, A., Girolami, V., Bijleveld van Lexmond, M., Bonmatin, J.-M., 2017. An update of the Worldwide Integrated Assessment (WIA) on systemic insecticides. Part 1: new molecules, metabolism, fate, and transport.

1243 Goldstein, A.H., Galbally, I.E., 2007. Known and Unexplored Organic Constituents in the Earth's Atmosphere. Environmental Science \& Technology 41, 1514-1521.

1248 Grannas, A.M., Hockaday, W.C., Hatcher, P.G., Thompson, L.G., Mosley-Thompson, E., 1249 2006. New revelations on the nature of organic matter in ice cores. Journal of Geophysical 1250 Research 111, D04304.

1251 Grannas, A.M., Shepson, P.B., Filley, T.R., 2004. Photochemistry and nature of organic 1252 matter in Arctic and Antarctic snow. Global Biogeochemical Cycles 18, n/a-n/a.

1253 Gregor, D.J., 1991. Organic micropollutants in seasonal snowcover and firn, in: Davies, T.D., 1254 Tranter, M., Jones, H.G. (Eds.), Seasonal Snowpacks. Processes of Compositional Change. 1255 Springer-Verlag.

1256 Gregor, D.J., Peters, A.J., Teixeira, C.F., Jones, N., Spencer, C., 1995. The historical residue 1257 trend of PCBs in the Agassiz Ice Cap, Ellesmere Island, Canada. Sci Total Environ 160-161, 1258 117-126.

1259 Grieman, M.M., Greaves, J., Saltzman, E.S., 2015. A method for analysis of vanillic acid in 1260 polar ice cores. Clim. Past. 11, 227-232. 
1261 Guenther, A., Karl, T., Harley, P., Wiedinmyer, C., Palmer, P.I., Geron, C., 2006. Estimates

1262 of global terrestrial isoprene emissions using MEGAN (Model of Emissions of Gases and

1263 Aerosols from Nature). Atmos Chem Phys 6, 3181-3210.

1264 Gustafsson, O., Andersson, P., Axelman, J., Bucheli, T.D., Komp, P., McLachlan, M.S., 1265 Sobek, A., Thorngren, J.O., 2005. Observations of the PCB distribution within and in1266 between ice, snow, ice-rafted debris, ice-interstitial water, and seawater in the Barents Sea 1267 marginal ice zone and the North Pole area. Sci Total Environ 342, 261-279.

1268 Hallquist, M., Wenger, J.C., Baltensperger, U., Rudich, Y., Simpson, D., Claeys, M., 1269 Dommen, J., Donahue, N.M., George, C., Goldstein, A.H., Hamilton, J.F., Herrmann, H., 1270 Hoffmann, T., Iinuma, Y., Jang, M., Jenkin, M.E., Jimenez, J.L., Kiendler-Scharr, A., 1271 Maenhaut, W., McFiggans, G., Mentel, T.F., Monod, A., Prévôt, A.S.H., Seinfeld, J.H., 1272 Surratt, J.D., Szmigielski, R., Wildt, J., 2009. The formation, properties and impact of 1273 secondary organic aerosol: current and emerging issues. Atmos Chem Phys 9, 5155-5236.

1274 Hardy, J.T., 1982. The sea surface microlayer: Biology, chemistry and anthropogenic 1275 enrichment. Progress in Oceanography 11, 307-328.

1276 Hennigan, C.J., Sullivan, A.P., Collett, J.L., Robinson, A.L., 2010. Levoglucosan stability in 1277 biomass burning particles exposed to hydroxyl radicals. Geophysical Research Letters 37.

1278 Hermanson, M.H., Isaksson, E., Teixeira, C., Muir, D.C.G., Compher, K.M., Li, Y.F., 1279 Igarashi, M., Kamiyama, K., 2005. Current-use and legacy pesticide history in the Austfonna 1280 ice cap, Svalbard, Norway. Environmental Science and Technology 39, 8163-8169.

1281 Ho, K.F., Lee, S.C., Ho, S.S.H., Kawamura, K., Tachibana, E., Cheng, Y., Zhu, T., 2010.

1282 Dicarboxylic acids, ketocarboxylic acids, $\alpha$-dicarbonyls, fatty acids, and benzoic acid in urban aerosols collected during the 2006 Campaign of Air Quality Research in Beijing (CAREBeijing-2006). Journal of Geophysical Research 115.

1285 Hodzic, A., Madronich, S., Bohn, B., Massie, S., Menut, L., Wiedinmyer, C., 2007. Wildfire particulate matter in Europe during summer 2003: meso-scale modeling of smoke emissions, transport and radiative effects. Atmos Chem Phys 7, 4043-4064.

1288 Hoffmann, D., Tilgner, A., Iinuma, Y., Herrmann, H., 2010. Atmospheric Stability of 1289 Levoglucosan: A Detailed Laboratory and Modeling Study. Environmental Science \& 1290 Technology 44, 694-699.

1291 Holmes, B.J., Petrucci, G.A., 2006. Water-soluble oligomer formation from acid-catalyzed 1292 reactions of levoglucosan in proxies of atmospheric aqueous aerosols. Environmental Science 1293 \& Technology 40, 4983-4989.

1294 Holmes, B.J., Petrucci, G.A., 2007. Oligomerization of levoglucosan by Fenton chemistry in 1295

1296 Hopmans, E.C., Weijers, J.W.H., Schefuß, E., Herfort, L., Sinninghe Damsté, J.S., Schouten, 1297 1298 S., 2004. A novel proxy for terrestrial organic matter in sediments based on branched and isoprenoid tetraether lipids. Earth Planet. Sci. Lett. 224, 107-116. 

aerosols over oceans via oxidation of isoprene and monoterpenes from Arctic to Antarctic. Sci Rep 3, 2280.

1302 Hung, H., Blanchard, P., Halsall, C.J., Bidleman, T.F., Stern, G.A., Fellin, P., Muir, D.C., Barrie, L.A., Jantunen, L.M., Helm, P.A., Ma, J., Konoplev, A., 2005. Temporal and spatial variabilities of atmospheric polychlorinated biphenyls (PCBs), organochlorine (OC) pesticides and polycyclic aromatic hydrocarbons (PAHs) in the Canadian Arctic: results from a decade of monitoring. Sci Total Environ 342, 119-144.

Ion, A.C., Vermeylen, R., Kourtchev, I., Cafmeyer, J., Chi, X., Gelencsér, A., Maenhaut, W., Claeys, M., 2005. Polar organic compounds in rural $\mathrm{PM}<\mathrm{sub}>2.5</$ sub $>$ aerosols from Kpuszta, Hungary, during a 2003 summer field campaign: Sources and diel variations. Atmos Chem Phys 5, 1805-1814.

1311 Isaksson, E., Hermanson, M., Hicks, S., Igarashi, M., Kamiyama, K., Moore, J., Motoyama, H., Muir, D., Pohjola, V., Vaikmäe, R., van de Wal, R.S.W., Watanabe, O., 2003. Ice cores from Svalbard - useful archives of past climate and pollution history. Physics and Chemistry of the Earth, Parts A/B/C 28, 1217-1228.

1315 Isaksson, E., Kekonen, T., Moore, J., Mulvaney, R., 2005. The methanesulfonic acid (MSA) record in a Svalbard ice core. Annals of Glaciology 42, 345-351.

1317 Jaffrezo, J.-L., Clain, M.P., Masclet, P., 1994. Polycyclic aromatic hydrocarbons in the polar 1318 ice of greenland. Geochemical use of these atmospheric tracers. Atmospheric Environment 1319 28, 1139-1145.

1320 Jaffrezo, J.-L., Masclet, P., Clain, M.P., Wortham, H., Beyne, S., Cachier, H., 1993. Transfer function of polycyclic aromatic hydrocarbons from the atmosphere to the polar ice- I. Determination of atmospheric concentrations at dye 3, Greenland. Atmospheric Environment. Part A. General Topics 27, 2781-2785.

Jaoui, M., Lewandowski, M., Kleindienst, T.E., Offenberg, J.H., Edney, E.O., 2007. $\beta$ caryophyllinic acid: An atmospheric tracer for $\beta$-caryophyllene secondary organic aerosol. 1326 Geophysical Research Letters 34.

Jauhiainen, T., Moore, J., Perämäki, P., Derome, J., Derome, K., 1999. Simple procedure for ion chromatographic determination of anions and cations at trace levels in ice core samples. Anal Chim Acta 389, 21-29.

1330 Jimenez, J.L., Canagaratna, M.R., Donahue, N.M., Prevot, A.S., Zhang, Q., Kroll, J.H., DeCarlo, P.F., Allan, J.D., Coe, H., Ng, N.L., Aiken, A.C., Docherty, K.S., Ulbrich, I.M., Grieshop, A.P., Robinson, A.L., Duplissy, J., Smith, J.D., Wilson, K.R., Lanz, V.A., Hueglin, C., Sun, Y.L., Tian, J., Laaksonen, A., Raatikainen, T., Rautiainen, J., Vaattovaara, P., Ehn, M., Kulmala, M., Tomlinson, J.M., Collins, D.R., Cubison, M.J., Dunlea, E.J., Huffman, J.A., Onasch, T.B., Alfarra, M.R., Williams, P.I., Bower, K., Kondo, Y., Schneider, J., Drewnick, F., Borrmann, S., Weimer, S., Demerjian, K., Salcedo, D., Cottrell, L., Griffin, R., Takami, A., Miyoshi, T., Hatakeyama, S., Shimono, A., Sun, J.Y., Zhang, Y.M., Dzepina, K., Kimmel, J.R., Sueper, D., Jayne, J.T., Herndon, S.C., Trimborn, A.M., Williams, L.R., Wood, E.C., Middlebrook, A.M., Kolb, C.E., Baltensperger, U., Worsnop, D.R., 2009. Evolution of organic aerosols in the atmosphere. Science 326, 1525-1529. 
1342 Iversen, P., Jouzel, J., Stauffer, B., steffensen, J.P., 1992. Irregular glacial interstadials recorded in a new Greenland ice core. Nature 359, 311-313.

1344 Jouzel, J., 2013. A brief history of ice core science over the last 50 yr. Clim. Past. 9, 252513452547.

1346 Kahl, J.D.W., Martinez, D.A., Kuhns, H., Davidson, C.I., Jaffrezo, J.-L., Harris, J.M., 1997. 1347 Air mass trajectories to Summit, Greenland: A 44-year climatology and some episodic 1348 events. Journal of Geophysical Research: Oceans 102, 26861-26875.

1349 Kallenborn, R., Breivik, K., Eckhardt, S., Lunder, C.R., Manø, S., Schlabach, M., Stohl, A., 2013. Long-term monitoring of persistent organic pollutants (POPs) at the Norwegian Troll station in Dronning Maud Land, Antarctica. Atmos. Chem. Phys. 13, 6983-6992. Deposition of organochlorine pesticides into the surface snow of East Antarctica. Sci Total 1354 Environ 433, 290-295.

Kawamura, K., 1993. Identification of C2-C10 .omega.-oxocarboxylic acids, pyruvic acid, and C2-C3 .alpha.-dicarbonyls in wet precipitation and aerosol samples by capillary GC and GC/MS. Analytical Chemistry 65, 3505-3511.

Kawamura, K., Bikkina, S., 2016. A review of dicarboxylic acids and related compounds in atmospheric aerosols: Molecular distributions, sources and transformation. Atmos. Res. 170, 140-160. https://doi.org/10.1016/j.atmosres.2015.11.018

1361 Kawamura, K., Izawa, Y., Mochida, M., Shiraiwa, T., 2012. Ice core records of biomass burning tracers (levoglucosan and dehydroabietic, vanillic and p-hydroxybenzoic acids) and total organic carbon for past 300 years in the Kamchatka Peninsula, Northeast Asia.

1364 Geochim. Cosmochim. Acta 99, 317 - 329.

1365 Kawamura, K., Suzuki, I., Fuji, Y., Watanabe, O., 1994. Ice core record of polycyclic 1366 aromatic hydrocarbons over the past 400 years. Naturwissenschaften 81, 502-505.

1367 Kawamura, K., Suzuki, I., Fujii, Y., Watanabe, O., 1996. Ice core record of fatty acids over 1368 the past 450 years in Greenland. Geophysical Research Letters 23, 2665-2668.

1369 Kawamura, K., Yokoyama, K., Fujii, Y., Watanabe, O., 1999. Implication of azelaic acid in a 1370 Greenland Ice Core for oceanic and atmospheric changes in high latitudes. Geophys. Res.

1371 Lett. 26, 871-874. https://doi.org/10.1029/1999GL900116

1372 Kawamura, K., Yokoyama, K., Fujii, Y., Watanabe, O., 2001. A Greenland ice core record of 1373 low molecular weight dicarboxylic acids, ketocarboxylic acids, and $\alpha$-dicarbonyls: A trend 1374 from Little Ice Age to the present (1540 to 1989 A.D.). J. Geophys. Res. Atmos. 106, 13311375 1345. https://doi.org/10.1029/2000JD900465

1376 Kehrwald, N., Zangrando, R., Gabrielli, P., Jaffrezo, J.L., Boutron, C., Barbante, C., 1377 Gambaro, A., 2012. Levoglucosan as a specific marker of fire events in Greenland snow. 1378 Tellus Ser. B-Chem. Phys. Meteorol. 64, 18196. 
1379 Kesselmeier, J., Kuhn, U., Wolf, A., Andreae, M.O., Ciccioli, P., Brancaleoni, E., Frattoni, 1380 M., Guenther, A., Greenberg, J., De Castro Vasconcellos, P., de Oliva, T., Tavares, T., Artaxo, P., 2000. Atmospheric volatile organic compounds (VOC) at a remote tropical forest site in central Amazonia. Atmospheric Environment 34, 4063-4072.

1383 Kirchgeorg, T., Schüpbach, S., Kehrwald, N., McWethy, D.B., Barbante, C., 2014. Method for the determination of specific molecular markers of biomass burning in lake sediments. Org Geochem 71, 1-6.

Kourtchev, I., Fuller, S., Aalto, J., Ruuskanen, T.M., McLeod, M.W., Maenhaut, W., Jones, R., Kulmala, M., Kalberer, M., 2013. Molecular composition of boreal forest aerosol from Hyytiala, Finland, using ultrahigh resolution mass spectrometry. Environ Sci Technol 47, 4069-4079.

1390 Kourtchev, I., Fuller, S.J., Giorio, C., Healy, R.M., Wilson, E., O'Connor, I., Wenger, J.C., McLeod, M., Aalto, J., Ruuskanen, T.M., Maenhaut, W., Jones, R., Venables, D.S., Sodeau, J.R., Kulmala, M., Kalberer, M., 2014. Molecular composition of biogenic secondary organic aerosols using ultrahigh-resolution mass spectrometry: Comparing laboratory and field studies. Atmos Chem Phys 14, 2155-2167.

1395 Kourtchev, I., Ruuskanen, T., Maenhaut, W., Kulmala, M., Claeys, M., 2005. Observation of 1396 2-methyltetrols and related photo-oxidation products of isoprene in boreal forest aerosols 1397 from Hyytiälä, Finland. Atmos Chem Phys 5, 2761-2770.

1398 Kroll, J.H., Donahue, N.M., Jimenez, J.L., Kessler, S.H., Canagaratna, M.R., Wilson, K.R., 1399 Altieri, K.E., Mazzoleni, L.R., Wozniak, A.S., Bluhm, H., Mysak, E.R., Smith, J.D., Kolb, 1400 C.E., Worsnop, D.R., 2011. Carbon oxidation state as a metric for describing the chemistry of 1401 atmospheric organic aerosol. Nat Chem 3, 133-139.

Kukučka, P., Lammel, G., Dvorská, A., Klánová, J., Möller, A., Fries, E., 2010. Contamination of Antarctic snow by polycyclic aromatic hydrocarbons dominated by combustion sources in the polar region. Environ Chem 7, 504.

1405 Lacorte, S., Quintana, J., Tauler, R., Ventura, F., Tovar-Sánchez, A., Duarte, C.M., 2009. 1406 Ultra-trace determination of Persistent Organic Pollutants in Arctic ice using stir bar sorptive extraction and gas chromatography coupled to mass spectrometry. J. Chromatogr. A 1216, 8581-8589. https://doi.org/10.1016/j.chroma.2009.10.029

1409 Laliberté, F., Howell, S.E.L., Kushner, P.J., 2016. Regional variability of a projected sea icefree Arctic during the summer months. Geophysical Research Letters 43, 256-263.

1411 Leck, C., Bigg, E.K., 2005. Source and evolution of the marine aerosol-A new perspective. 1412 Geophysical Research Letters 32, n/a-n/a.

1413 Legrand, M., De Angelis, M., 1995. Origins and variations of light carboxylic acids in polar 1414 precipitation. Journal of Geophysical Research: Atmospheres 100, 1445-1462.

1415 Legrand, M., De Angelis, M., 1996. Light carboxylic acids in Greenland ice: A record of past 1416 forest fires and vegetation emissions from the boreal zone. J. Geophys. Res. 101, 4129. 1417 https://doi.org/10.1029/95JD03296 
1418 Legrand, M., De Angelis, M., Maupetit, F., 1993. Field investigation of major and minor ions

1419 along Summit (Central Greenland) ice cores by ion chromatography. Journal of

1420 Chromatography A 640, 251-258.

1421 Legrand, M., Hammer, C., De Angelis, M., Savarino, J., Delmas, R., Clausen, H., Johnsen, 1422 S.J., 1997. Sulfur-containing species (methanesulfonate and SO4) over the last climatic cycle in the Greenland Ice Core Project (central Greenland) ice core. Journal of Geophysical Research: Oceans 102, 26663-26679.

Legrand, M., Preunkert, S., Jourdain, B., Guilhermet, J., Fan, X., Alekhina, I., Petit, J.R., 2013. Water-soluble organic carbon in snow and ice deposited at Alpine, Greenland, and Antarctic sites: a critical review of available data and their atmospheric relevance. Clim. Past. 9, 2195-2211.

1429 Levine, J.G., Wolff, E.W., Jones, A.E., Hutterli, M.A., Wild, O., Carver, G.D., Pyle, J.A., 2011a. In search of an ice core signal to differentiate between source-driven and sink-driven changes in atmospheric methane. J. Geophys. Res. 116, D05305. https://doi.org/10.1029/2010JD014878

1433 Levine, J.G., Wolff, E.W., Jones, A.E., Sime, L.C., Valdes, P.J., Archibald, A.T., Carver, 1434 G.D., Warwick, N.J., Pyle, J.A., 2011b. Reconciling the changes in atmospheric methane sources and sinks between the Last Glacial Maximum and the pre-industrial era. Geophysical Research Letters 38, n/a-n/a.

1437 Li, Q.L., Wang, N.L., Wu, X.B., Pu, J.C., He, J.Q., Zhang, C.W., 2011. Sources and 1438 distribution of polycyclic aromatic hydrocarbons of different glaciers over the Tibetan 1439 Plateau. Sci. China-Earth Sci. 54, 1189-1198.

1440 Lohmann, R., Gioia, R., Jones, K.C., Nizzetto, L., Temme, C., Xie, Z., Schulz-Bull, D., Hand, I., Morgan, E., Jantunen, L., 2009. Organochlorine Pesticides and PAHs in the Surface Water and Atmosphere of the North Atlantic and Arctic Ocean. Environmental Science \& Technology 43, 5633-5639.

1444 Ma, J., Hung, H., Tian, C., Kallenborn, R., 2011. Revolatilization of persistent organic 1445 pollutants in the Arctic induced by climate change. Nat Clim Change 1, 255-260.

1446 Macdonald, R.W., Barrie, L.A., Bidleman, T.F., Diamond, M.L., Gregor, D.J., Semkin, R.G., Strachan, W.M.J., Li, Y.F., Wania, F., Alaee, M., Alexeeva, L.B., Backus, S.M., Bailey, R., Bewers, J.M., Gobeil, C., Halsall, C.J., Harner, T., Hoff, J.T., Jantunen, L.M.M., Lockhart, W.L., Mackay, D., Muir, D.C.G., Pudykiewicz, J., Reimer, K.J., Smith, J.N., Stern, G.A., Schroeder, W.H., Wagemann, R., Yunker, M.B., 2000. Contaminants in the Canadian Arctic: 5 years of progress in understanding sources, occurrence and pathways. Sci Total Environ $254,93-234$.

1453 MacFarling Meure, C., Etheridge, D., Trudinger, C., Steele, P., Langenfelds, R., van Ommen, 1454 T., Smith, A., Elkins, J., 2006. Law Dome CO2, CH4and N2O ice core records extended to 14552000 years BP. Geophysical Research Letters 33.

1456 Marino, F., Castellano, E., Ceccato, D., De Deckker, P., Delmonte, B., Ghermandi, G., 1457 Maggi, V., Petit, J.R., Revel-Rolland, M., Udisti, R., 2008. Defining the geochemical 
composition of the EPICA Dome $\mathrm{C}$ ice core dust during the last glacial-interglacial cycle. Geochem. Geophys. Geosyst. 9.

1460 Masclet, P., Hoyau, V., Jaffrezo, J., Legrand, M., 1995. Evidence for the Presence of 1461 Polycyclic Aromatic-Hydrocarbons in the Polar Atmosphere and in the Polar Ice of 1462 Greenland. Analusis 23, 250-252.

1463 Masclet, P., Hoyau, V., Jaffrezo, J.L., Cachier, H., 2000. Polycyclic aromatic hydrocarbon 1464 deposition on the ice sheet of Greenland. Part I: Superficial snow. Atmospheric Environment $146534,3195-3207$.

McConnell, J.R., Edwards, R., Kok, G.L., Flanner, M.G., Zender, C.S., Saltzman, E.S., Banta, J.R., Pasteris, D.R., Carter, M.M., Kahl, J.D.W., 2007. 20th-century industrial black carbon emissions altered arctic climate forcing. Science 317, 1381-1384.

Mochida, M., Kitamori, Y., Kawamura, K., Nojiri, Y., Suzuki, K., 2002. Fatty acids in the marine atmosphere: Factors governing their concentrations and evaluation of organic films on sea-salt particles. Journal of Geophysical Research: Atmospheres 107, AAC 1-1-AAC 1-10.

Muir, D.C.G., Teixeira, C., Wania, F., 2004. Empirical and Modeling Evidence of Regional Atmospheric Transport of Current-Use Pesticides. Environ Toxicol Chem 23, 2421.

Muir, D.C.G., Wagemann, R., Hargrave, B.T., Thomas, D.J., Peakall, D.B., Norstrom, R.J., 1992. Arctic marine ecosystem contamination. Sci Total Environ 122, 75-134.

Müller-Tautges, C., Eichler, A., Schwikowski, M., Hoffmann, T., 2014. A new sensitive method for the quantification of glyoxal and methylglyoxal in snow and ice by stir bar sorptive extraction and liquid desorption-HPLC-ESI-MS. Anal Bioanal Chem 406, 2525 2532.

1480 Müller-Tautges, C., Eichler, A., Schwikowski, M., Pezzatti, G.B., Conedera, M., Hoffmann, T., 2016. Historic records of organic compounds from a high Alpine glacier: Influences of biomass burning, anthropogenic emissions, and dust transport. Atmos. Chem. Phys. 16, 1029-1043. https://doi.org/10.5194/acp-16-1029-2016

1484 Na, G., Liu, C., Wang, Z., Ge, L., Ma, X., Yao, Z., 2011. Distribution and characteristic of 1485 PAHs in snow of Fildes Peninsula. Journal of Environmental Sciences 23, 1445-1451.

1486 Nielsen, T., 1996. Traffic contribution of polycyclic aromatic hydrocarbons in the center of a 1487 large city. Atmospheric Environment 30, 3481-3490.

1488 Noziere, B., Kalberer, M., Claeys, M., Allan, J., D'Anna, B., Decesari, S., Finessi, E., 1489 Glasius, M., Grgic, I., Hamilton, J.F., Hoffmann, T., Iinuma, Y., Jaoui, M., Kahnt, A., 1490 Kampf, C.J., Kourtchev, I., Maenhaut, W., Marsden, N., Saarikoski, S., Schnelle-Kreis, J., Surratt, J.D., Szidat, S., Szmigielski, R., Wisthaler, A., 2015. The molecular identification of organic compounds in the atmosphere: state of the art and challenges. Chem Rev 115, 39193983.

1494 O'Dowd, C.D., Facchini, M.C., Cavalli, F., Ceburnis, D., Mircea, M., Decesari, S., Fuzzi, S., 
1497 O'Dwyer, J., Isaksson, E., Vinje, T., Jauhiainen, T., Moore, J., Pohjola, V., Vaikmäe, R., van 1498 de Wal, R.S.W., 2000. Methanesulfonic acid in a Svalbard Ice Core as an indicator of ocean 1499 climate. Geophysical Research Letters 27, 1159-1162.

1500 OECD, 2013. OECD/UNEP Global PFC Group, Synthesis on per- and polyfluorinated 1501 chemicals (PFCs), Environment, Health and Safety, Environment Directorate, OECD.

1502 Pancost, R.D., Boot, C.S., 2004. The palaeoclimatic utility of terrestrial biomarkers in marine 1503 sediments. Mar Chem 92, 239-261.

1504 Pavlova, P.A., Jenk, T.M., Schmid, P., Bogdal, C., Steinlin, C., Schwikowski, M., 2015.

1505 Polychlorinated Biphenyls in a Temperate Alpine Glacier: 1. Effect of Percolating Meltwater 1506 on their Distribution in Glacier Ice. Environ Sci Technol 49, 14085-14091.

1507 Pavlova, P.A., Schmid, P., Zennegg, M., Bogdal, C., Schwikowski, M., 2014. Trace analysis 1508 of hydrophobic micropollutants in aqueous samples using capillary traps. Chemosphere 106, $1509 \quad 51-56$.

1510 Peel, D.A., 1975. Organochlorine residues in Antarctic snow. Nature 254, 324-325.

1511 Perrette, M., Yool, A., Quartly, G.D., Popova, E.E., 2011. Near-ubiquity of ice-edge blooms 1512 in the Arctic. Biogeosciences 8, 515-524.

1513 Peters, A.J., Gregor, D.J., Teixeira, C.F., Jones, N.P., Spencer, C., 1995. The recent 1514 depositional trend of polycyclic aromatic hydrocarbons and elemental carbon to the Agassiz 1515 Ice Cap, Ellesmere Island, Canada. The Science of The Total Environment 160-161, 167-179.

1516 Piazza, R., Gambaro, A., Argiriadis, E., Vecchiato, M., Zambon, S., Cescon, P., Barbante, C., 1517 2013. Development of a method for simultaneous analysis of PCDDs, PCDFs, PCBs, PBDEs, 1518 PCNs and PAHs in Antarctic air. Anal Bioanal Chem 405, 917-932.

1519 Pokhrel, A., 2015. Studies on ice core records of dicarboxylic acids, $\omega$-oxocarboxylic acids, 1520 pyruvic acid, $\alpha$-dicarbonyls and fatty acids from southern Alaska since 1665AD: A link to 1521 climate change in the Northern Hemisphere. Hokkaido University.

1522 Pokhrel, A., Kawamura, K., Ono, K., Seki, O., Fu, P., Matoba, S., Shiraiwa, T., 2016. Ice 1523 core records of monoterpene- and isoprene-SOA tracers from Aurora Peak in Alaska since 1524 1660s: Implication for climate change variability in the North Pacific Rim. Atmospheric 1525 Environment 130, 105-112.

1526 Pokhrel, A., Kawamura, K., Seki, O., Matoba, S., Shiraiwa, T., 2015. Ice core profiles of 1527 saturated fatty acids (C12:0-C30:0) and oleic acid (C18:1) from southern Alaska since 1734 1528 AD: A link to climate change in the Northern Hemisphere. Atmospheric Environment 100, $1529 \quad 202-209$.

1530 Preunkert, S., Jourdain, B., Legrand, M., Udisti, R., Becagli, S., Cerri, O., 2008. Seasonality 1531 of sulfur species (dimethyl sulfide, sulfate, and methanesulfonate) in Antarctica: Inland 1532 versus coastal regions. Journal of Geophysical Research 113.

1533 Prevedouros, K., Cousins, I.T., Buck, R.C., Korzeniowski, S.H., 2006. Sources, Fate and 1534 Transport of Perfluorocarboxylates. Environmental Science \& Technology 40, 32-44. 

carbon. Nat Geosci 1, 221-227.

1537 Rhodes, R.H., Bertler, N.A.N., Baker, J.A., Sneed, S.B., Oerter, H., Arrigo, K.R., 2009. Sea ice variability and primary productivity in the Ross Sea, Antarctica, from methylsulphonate snow record. Geophysical Research Letters 36.

1540 Rinne, H.J.I., Guenther, A.B., Greenberg, J.P., Harley, P.C., 2002. Isoprene and monoterpene fluxes measured above Amazonian rainforest and their dependence on light and temperature. Atmospheric Environment 36, 2421-2426.

Rontani, J.F., Charriere, B., Vaultier, F., Garcia, N., Sempéré, R., Raimbault, P., 2012. Origin and degradation of lipids in aeolian particles from a coastal area of the north-western Mediterranean Sea. Atmospheric Environment 56, 124-135.

Rubino, M., DOnofrio, A., Seki, O., Bendle, J.A., 2016. Ice-core records of biomass burning. The Anthropocene Review 3, 140-162.

Ruggirello, R.M., Hermanson, M.H., Isaksson, E., Teixeira, C., Forsström, S., Muir, D.C.G., deposition to ice caps on Svalbard, Norway. Journal of Geophysical Research 115, D18308.

Saltzman, E.S., Dioumaeva, I., Finley, B.D., 2006. Glacial/interglacial variations in methanesulfonate (MSA) in the Siple Dome ice core, West Antarctica. Geophysical Research Letters 33, 1-4.

1554 Saltzman, E.S., Whung, P.Y., Mayewski, P.A., 1997. Methanesulfonate in the Greenland Ice Sheet Project 2 ice core. Journal of Geophysical Research 102, 26649-26657. in Hokkaido, Japan: Implications for Ice Core Studies. Arctic, Antarctic, and Alpine Research $45,119-131$.

1559 Sapart, C.J., Monteil, G., Prokopiou, M., van de Wal, R.S.W., Kaplan, J.O., Sperlich, P., 1560 Krumhardt, K.M., van der Veen, C., Houweling, S., Krol, M.C., Blunier, T., Sowers, T., 1561 Martinerie, P., Witrant, E., Dahl-Jensen, D., Rockmann, T., 2012. Natural and anthropogenic 1562 variations in methane sources during the past two millennia. Nature 490, 85-88.

1563 Scheringer, M., Stroebe, M., Wania, F., Wegmann, F., Hungerbühler, K., 2004. The effect of 1564 export to the deep sea on the long-range transport potential of persistent organic pollutants.

1565 Environmental Science and Pollution Research 11, 41-48.

1566 Schmid, P., Bogdal, C., Bluthgen, N., Anselmetti, F.S., Zwyssig, A., Hungerbuhler, K., 2011. 1567 The missing piece: sediment records in remote Mountain lakes confirm glaciers being 1568 secondary sources of persistent organic pollutants. Environ Sci Technol 45, 203-208.

1569 Schmitt-Kopplin, P., Liger-Belair, G., Koch, B.P., Flerus, R., Kattner, G., Harir, M., 1570 Kanawati, B., Lucio, M., Tziotis, D., Hertkorn, N., Gebefügi, I., 2012. Dissolved organic matter in sea spray: a transfer study from marine surface water to aerosols. Biogeosciences 9 , 1571-1582. 
1574 Carbonaceous aerosol tracers in ice-cores record multi-decadal climate oscillations. Scientific 1575 Reports 5, 14450.

1576 Sharkey, T.D., Wiberley, A.E., Donohue, A.R., 2008. Isoprene emission from plants: why 1577 and how. Ann Bot 101, 5-18.

1578 Sharma, S., Chan, E., Ishizawa, M., Toom-Sauntry, D., Gong, S.L., Li, S.M., Tarasick, D.W., Leaitch, W.R., Norman, A., Quinn, P.K., Bates, T.S., Levasseur, M., Barrie, L.A., Maenhaut, W., 2012. Influence of transport and ocean ice extent on biogenic aerosol sulfur in the Arctic atmosphere. Journal of Geophysical Research: Atmospheres 117, n/a-n/a.

Sheldon, S.G., Steffensen, J.P., Hansen, S.B., Popp, T.J., Johnsen, S.J., 2014. The investigation and experience of using ESTISOL ${ }^{\mathrm{TM}} 240$ and COASOL ${ }^{\mathrm{TM}}$ for ice-core drilling. Annals of Glaciology 55, 219-232. 8793.

1588 Siggaard-Andersen, M.L., Gabrielli, P., Steffensen, J.P., Stromfeldt, T., Barbante, C., 1589 Boutron, C., Fischer, H., Miller, H., 2007. Soluble and insoluble lithium dust in the EPICA 1590 DomeC ice core - Implications for changes of the East Antarctic dust provenance during the 1591 recent glacial-interglacial transition. Earth Planet. Sci. Lett. 258, 32-43.

1592 Simon-Delso, N., Amaral-Rogers, V., Belzunces, L.P., Bonmatin, J.M., Chagnon, M., 1593 Downs, C., Furlan, L., Gibbons, D.W., Giorio, C., Girolami, V., Goulson, D., Kreutzweiser, 1594 D.P., Krupke, C.H., Liess, M., Long, E., Mcfield, M., Mineau, P., Mitchell, E.A., Morrissey, 1595 C.A., Noome, D.A., Pisa, L., Settele, J., Stark, J.D., Tapparo, A., Van Dyck, H., Van Praagh, 1596 J., Van Der Sluijs, J.P., Whitehorn, P.R., Wiemers, M., 2015. Systemic insecticides 1597 (Neonicotinoids and fipronil): Trends, uses, mode of action and metabolites. Environmental 1598 Science and Pollution Research 22, 5-34.

1599 Simoneit, B.R.T., 2002. Biomass burning - A review of organic tracers for smoke from 1600 incomplete combustion. Appl. Geochem. 17, 129-162.

1601 Sinclair, K.E., Bertler, N.A.N., Bowen, M.M., Arrigo, K.R., 2014. Twentieth century sea-ice trends in the Ross Sea from a high-resolution, coastal ice-core record. Geophysical Research Letters 41, 3510-3516.

1604 Slater, J.F., Currie, L.A., Dibb, J.E., Benner, B.A., 2002. Distinguishing the relative contribution of fossil fuel and biomass combustion aerosols deposited at Summit, Greenland through isotopic and molecular characterization of insoluble carbon. Atmospheric Environment 36, 4463-4477.

1610

Sorooshian, A., Padró, L.T., Nenes, A., Feingold, G., McComiskey, A., Hersey, S.P., Gates,

1611 H., Jonsson, H.H., Miller, S.D., Stephens, G.L., Flagan, R.C., Seinfeld, J.H., 2009. On the link between ocean biota emissions, aerosol, and maritime clouds: Airborne, ground, and satellite measurements off the coast of California. Global Biogeochemical Cycles 23, n/a-n/a. 
1612 Steinlin, C., Bogdal, C., Scheringer, M., Pavlova, P.A., Schwikowski, M., Schmid, P.,

1613 Hungerbuhler, K., 2014. Polychlorinated biphenyls in glaciers. 2. Model results of deposition and incorporation processes. Environ Sci Technol 48, 7849-7857.

1615 Stortini, A.M., Martellini, T., Del Bubba, M., Lepri, L., Capodaglio, G., Cincinelli, A., 2009. 1616 n-Alkanes, PAHs and surfactants in the sea surface microlayer and sea water samples of the 1617 Gerlache Inlet sea (Antarctica). Microchem. J. 92, 37-43.

1618 https://doi.org/10.1016/j.microc.2008.11.005

1619 Surratt, J.D., Lewandowski, M., Offenberg, J.H.; Jaoui, M., Kleindienst, T.E., Edney, E.O., 1620 Seinfeld, J.H., 2007. Effect of acidity on secondary organic aerosol formation from isoprene. 1621 Environ Sci Technol 41, 5363-5369.

1622 Talalay, P.G., Gundestrup, N.S., 2002. Hole fluids for deep ice core drilling. Memoirs of 1623 National Institute of Polar Research. Special issue 56, 148-170.

1624 Taylor, K.C., Mayewski, P.A., Twickler, M.S., Whitlow, S.I., 1996. Biomass burning recorded in the GISP2 ice core: A record from eastern Canada? Holocene 6, 1-6.

1626 Thomas, E.R., Abram, N.J., 2016. Ice core reconstruction of sea ice change in the Amundsen1627 Ross Seas since 1702 A.D. Geophysical Research Letters 43, 5309-5317.

1628 Trentmann, J., Luderer, G., Winterrath, T., Fromm, M.D., Servranckx, R., Textor, C., 1629 Herzog, M., Graf, H.F., Andreae, M.O., 2006. Modeling of biomass smoke injection into the 1630 lower stratosphere by a large forest fire (Part I): reference simulation. Atmos Chem Phys 6, $16315247-5260$.

1632 Trostl, J., Chuang, W.K., Gordon, H., Heinritzi, M., Yan, C., Molteni, U., Ahlm, L., Frege, 1633 C., Bianchi, F., Wagner, R., Simon, M., Lehtipalo, K., Williamson, C., Craven, J.S., 1634 Duplissy, J., Adamov, A., Almeida, J., Bernhammer, A.K., Breitenlechner, M., Brilke, S., 1635 Dias, A., Ehrhart, S., Flagan, R.C., Franchin, A., Fuchs, C., Guida, R., Gysel, M., Hansel, A., 1636 Hoyle, C.R., Jokinen, T., Junninen, H., Kangasluoma, J., Keskinen, H., Kim, J., Krapf, M., 1637 Kurten, A., Laaksonen, A., Lawler, M., Leiminger, M., Mathot, S., Mohler, O., Nieminen, T., Onnela, A., Petaja, T., Piel, F.M., Miettinen, P., Rissanen, M.P., Rondo, L., Sarnela, N., Schobesberger, S., Sengupta, K., Sipila, M., Smith, J.N., Steiner, G., Tome, A., Virtanen, A., Wagner, A.C., Weingartner, E., Wimmer, D., Winkler, P.M., Ye, P., Carslaw, K.S., Curtius, J., Dommen, J., Kirkby, J., Kulmala, M., Riipinen, I., Worsnop, D.R., Donahue, N.M., Baltensperger, U., 2016. The role of low-volatility organic compounds in initial particle growth in the atmosphere. Nature 533, 527-531.

1644 Tsigaridis, K., Daskalakis, N., Kanakidou, M., Adams, P.J., Artaxo, P., Bahadur, R., Balkanski, Y., Bauer, S.E., Bellouin, N., Benedetti, A., Bergman, T., Berntsen, T.K., Beukes, J.P., Bian, H., Carslaw, K.S., Chin, M., Curci, G., Diehl, T., Easter, R.C., Ghan, S.J., Gong, S.L., Hodzic, A., Hoyle, C.R., Iversen, T., Jathar, S., Jimenez, J.L., Kaiser, J.W., Kirkevåg, A., Koch, D., Kokkola, H., Lee, Y.H., Lin, G., Liu, X., Luo, G., Ma, X., Mann, G.W., Mihalopoulos, N., Morcrette, J.J., Müller, J.F., Myhre, G., Myriokefalitakis, S., Ng, N.L., O'Donnell, D., Penner, J.E., Pozzoli, L., Pringle, K.J., Russell, L.M., Schulz, M., Sciare, J., Seland, Ø., Shindell, D.T., Sillman, S., Skeie, R.B., Spracklen, D., Stavrakou, T., Steenrod, S.D., Takemura, T., Tiitta, P., Tilmes, S., Tost, H., van Noije, T., van Zyl, P.G., von Salzen, K., Yu, F., Wang, Z., Wang, Z., Zaveri, R.A., Zhang, H., Zhang, K., Zhang, Q., Zhang, X., 
2014. The AeroCom evaluation and intercomparison of organic aerosol in global models. Atmos Chem Phys 14, 10845-10895.

1656 Uglietti, C., Zapf, A., Jenk, T.M., Sigl, M., Szidat, S., Salazar, G., Schwikowski, M., 2016. 1657 Radiocarbon dating of glacier ice: overview, optimisation, validation and potential. The 1658 Cryosphere 10, 3091-3105.

1659 UNEP, 2004. Stockholm Convention on Persistent Organic Pollutants. United Nations 1660 Environemt Programme: Nairobi, Kenya.

1661 Vallelonga, P., Gabrielli, P., Balliana, E., Wegner, A., Delmonte, B., Turetta, C., Burton, G., 1662 Vanhaecke, F., Rosman, K.J.R., Hong, S., Boutron, C.F., Cescon, P., Barbante, C., 2010. 1663 Lead isotopic compositions in the EPICA Dome C ice core and Southern Hemisphere 1664 Potential Source Areas. Quat. Sci. Rev. 29, 247-255.

1665 van Eijck, A., Opatz, T., Taraborrelli, D., Sander, R., Hoffmann, T., 2013. New tracer 1666 compounds for secondary organic aerosol formation from $\beta$-caryophyllene oxidation. 1667 Atmospheric Environment 80, 122-130.

1668 Vecchiato, M., Argiriadis, E., Zambon, S., Barbante, C., Toscano, G., Gambaro, A., Piazza, 1669 R., 2015. Persistent Organic Pollutants (POPs) in Antarctica: Occurrence in continental and 1670 coastal surface snow. Microchem J 119, 75-82.

1671 Vehvilainen, J., Isaksson, E., Moore, J.C., 2002. A 20th-century record of naphthalene in an ice core from Svalbard. Annals of Glaciology 35, 257-260.

1673 Vignati, E., Facchini, M.C., Rinaldi, M., Scannell, C., Ceburnis, D., Sciare, J., Kanakidou, 1674 M., Myriokefalitakis, S., Dentener, F., O'Dowd, C.D., 2010. Global scale emission and distribution of sea-spray aerosol: Sea-salt and organic enrichment. Atmospheric Environment $167644,670-677$.

1677 Virtanen, A., Joutsensaari, J., Koop, T., Kannosto, J., Yli-Pirila, P., Leskinen, J., Makela, 1678 J.M., Holopainen, J.K., Poschl, U., Kulmala, M., Worsnop, D.R., Laaksonen, A., 2010. An 1679 amorphous solid state of biogenic secondary organic aerosol particles. Nature 467, 824-827.

1680 von Schneidemesser, E., Schauer, J.J., Shafer, M.M., Hagler, G.S.W., Bergin, M.H., Steig, 1681 E.J., 2008. A method for the analysis of ultra-trace levels of semi-volatile and non-volatile 1682 organic compounds in snow and application to a Greenland snow pit. Polar Science 2, 2511683266.

1684 Wang, W., Wu, M.H., Li, L., Zhang, T., Liu, X.D., Feng, J.L., Li, H.J., Wang, Y.J., Sheng,

1687 Wang, Z., Chappellaz, J., Martinerie, P., Park, K., Petrenko, V., Witrant, E., Emmons, L.K., 1688 Blunier, T., Brenninkmeijer, C.A.M., Mak, J.E., 2012. The isotopic record of Northern 1689 Hemisphere atmospheric carbon monoxide since 1950: implications for the CO budget. 1690 Atmos Chem Phys 12, 4365-4377.

1691 Wang, Z., Chappellaz, J., Park, K., Mak, J.E., 2010. Large Variations in Southern 1692 Hemisphere Biomass Burning During the Last 650 Years. Science 330, 1663-1666. 
1693 Wang, Z., Cousins, I.T., Scheringer, M., Buck, R.C., Hungerbuhler, K., 2014. Global

1694 emission inventories for C4-C14 perfluoroalkyl carboxylic acid (PFCA) homologues from

16951951 to 2030, part II: the remaining pieces of the puzzle. Environ Int 69, 166-176.

1696 Wang, Z., Xie, Z., Mi, W., Möller, A., Wolschke, H., Ebinghaus, R., 2015. Neutral Poly/Per-

1697 Fluoroalkyl Substances in Air from the Atlantic to the Southern Ocean and in Antarctic

1698 Snow. Environmental Science \& Technology 49, 7770-7775.

1699 Wania, F., 2006. Potential of Degradable Organic Chemicals for Absolute and Relative

1700 Enrichment in the Arctic. Environmental Science \& Technology 40, 569-577.

1701 Wania, F., Hoff, J.T., Jia, C.Q., Mackay, D., 1998. The effects of snow and ice on the

1702 environmental behaviour of hydrophobic organic chemicals. Environ Pollut 102, 25-41.

1703 Wania, F., Mackay, D., 1996. Peer reviewed: tracking the distribution of persistent organic

1704 pollutants. Environ Sci Technol 30, 390A-396A.

1705 Welch, K.A., Mayewski, P.A., Whitlow, S.I., 1993. Methanesulfonic acid in coastal Antarctic

1706 snow related to sea-ice extent. Geophysical Research Letters 20, 443-446.

1707 Whung, P.-Y., Saltzman, E.S., Spencer, M.J., Mayewski, P.a., Gundestrup, N., 1994. Two-

1708 hundred-year record of biogenic sulfur in a south Greenland ice core (20D). Journal of

1709 Geophysical Research 99, 1147.

1710 Wohrnschimmel, H., MacLeod, M., Hungerbuhler, K., 2013. Emissions, fate and transport of 1711 persistent organic pollutants to the Arctic in a changing global climate. Environ Sci Technol $171247,2323-2330$.

1713 Wolff, E.W., 2012. Chemical signals of past climate and environment from polar ice cores

1715 Wolff, E.W., Fischer, H., Fundel, F., Ruth, U., Twarloh, B., Littot, G.C., Mulvaney, R., 1716 Röthlisberger, R., De Angelis, M., Boutron, C.F., Hansson, M., Jonsell, U., Hutterli, M.a., 1717 Lambert, F., Kaufmann, P., Stauffer, B., Stocker, T.F., Steffensen, J.P., Bigler, M., Siggaard1718 Andersen, M.L., Udisti, R., Becagli, S., Castellano, E., Severi, M., Wagenbach, D., Barbante, 1719 C., Gabrielli, P., Gaspari, V., 2006. Southern Ocean sea-ice extent, productivity and iron flux 1720 over the past eight glacial cycles. Nature 440, 491-496.

1721 Wurl, O., Ekau, W., Landing, W.M., Zappa, C.J., 2017. Sea surface microlayer in a changing ocean - A perspective. Elem Sci Anth 5, 31. https://doi.org/10.1525/elementa.228

1723 Wurl, O., Obbard, J.P., 2004. A review of pollutants in the sea-surface microlayer (SML): a unique habitat for marine organisms. Mar. Pollut. Bull. 48, 1016-1030. https://doi.org/10.1016/j.marpolbul.2004.03.016

Xia, X., Hopke, P.K., 2006. Seasonal Variation of 2-Methyltetrols in Ambient Air Samples. 
1731 Xie, Z., Wang, Z., Mi, W., Möller, A., Wolschke, H., Ebinghaus, R., 2015. Neutral Poly1732 /perfluoroalkyl Substances in Air and Snow from the Arctic. Scientific Reports 5, 8912.

1733 Xie, Z., Zhao, Z., Moller, A., Wolschke, H., Ahrens, L., Sturm, R., Ebinghaus, R., 2013.

1734 Neutral poly- and perfluoroalkyl substances in air and seawater of the North Sea. Environ Sci

1735 Pollut Res Int 20, 7988-8000.

1736 Yamamoto, S., Kawamura, K., Seki, O., 2011. Long-range atmospheric transport of 1737 terrestrial biomarkers by the Asian winter monsoon: Evidence from fresh snow from 1738 Sapporo, northern Japan. Atmospheric Environment 45, 3553-3560.

1739 Yamashita, N., Kannan, K., Taniyasu, S., Horii, Y., Petrick, G., Gamo, T., 2005. A global 1740 survey of perfluorinated acids in oceans. Mar Pollut Bull 51, 658-668.

1741 Yao, P., Schwab, V.F., Roth, V., Xu, B., Yao, T., Gleixner, G., 2013. Levoglucosan concentrations in ice-core samples from the Tibetan Plateau determined by reverse-phase high-performance liquid chromatography-mass spectrometry. J Glaciol 59, 599-608.

1744 Yassaa, N., Peeken, I., Zöllner, E., Bluhm, K., Arnold, S., Spracklen, D., Williams, J., 2008.

1745 Evidence for marine production of monoterpenes. Environ Chem 5, 391-401.

You, C., Song, L., Xu, B., Gao, S., 2016. Method for determination of levoglucosan in snow and ice at trace concentration levels using ultra-performance liquid chromatography coupled with triple quadrupole mass spectrometry. Talanta 148, 534-538.

1749 You, C., Yao, T., Gao, S., Gong, P., Zhao, H., 2014. Simultaneous Determination of 1750 Levoglucosan, Mannosan and Galactosan at Trace Levels in Snow Samples by GC/MS. 1751 Chromatographia 77, 969-974.

1752 Young, C.J., Furdui, V.I., Franklin, J., Koerner, R.M., Muir, D.C.G., Mabury, S.A., 2007. 1753 Perfluorinated Acids in Arctic Snow: New Evidence for Atmospheric Formation. 1754 Environmental Science \& Technology 41, 3455-3461.

1755 Yunker, M.B., Macdonald, R.W., 1995. Composition and Origins of Polycyclic Aromatic 1756 Hydrocarbons in the Mackenzie River and on the Beaufort Sea Shelf. Arctic 48, 118-129.

1757 Zangrando, R., Barbaro, E., Zennaro, P., Rossi, S., Kehrwald, N.M., Gabrieli, J., Barbante, 1758 C., Gambaro, A., 2013. Molecular Markers of Biomass Burning in Arctic Aerosols.

1759 Environmental Science \& Technology 47, 8565-8574.

1760 Zennaro, P., Kehrwald, N., Marlon, J., Ruddiman, W.F., Brücher, T., Agostinelli, C., Dahl1761 Jensen, D., Zangrando, R., Gambaro, A., Barbante, C., 2015. Europe on fire three thousand 1762 years ago: Arson or climate? Geophysical Research Letters 42, 5023-2033.

1763 Zennaro, P., Kehrwald, N., McConnell, J.R., Schüpbach, S., Maselli, O.J., Marlon, J., 1764 Vallelonga, P., Leuenberger, D., Zangrando, R., Spolaor, A., Borrotti, M., Barbaro, E., 1765 Gambaro, A., Barbante, C., 2014. Fire in ice: two millennia of boreal forest fire history from 1766 the Greenland NEEM ice core. Clim. Past 10, 1905-1924.

1767 Zhang, X., Meyer, T., Muir, D.C., Teixeira, C., Wang, X., Wania, F., 2013. Atmospheric 1768 deposition of current use pesticides in the Arctic: snow core records from the Devon Island 1769 Ice Cap, Nunavut, Canada. Environ Sci Process Impacts 15, 2304-2311. 
1770 Zoccolillo, L., Amendola, L., Cafaro, C., Insogna, S., 2005. Improved analysis of volatile 1771 halogenated hydrocarbons in water by purge-and-trap with gas chromatography and mass 1772 spectrometric detection. J. Chromatogr. A 1077, 181-187.

1773 https://doi.org/10.1016/j.chroma.2005.04.076

1774

1775 